\title{
Margin Trading Program, External Profit Pressure and Enterprise Financialization-A Quasi-Natural Experiment Based on Double Difference Model
}

\author{
Shuiwen Gao ${ }^{1}$, Haifeng Gu ${ }^{1, *}$ and Habiba Halepoto ${ }^{2}$ (D) \\ 1 Glorious Sun School of Business and Management, Donghua University, Shanghai 200051, China; \\ wennysw@hotmail.com \\ 2 Engineering Research Center of Digitized Textile and Fashion Technology, Donghua University, \\ Shanghai 201620, China; 317111@mail.dhu.edu.cn \\ * Correspondence: dhughf@163.com
}

Citation: Gao, S.; Gu, H.; Halepoto, H. Margin Trading Program, External Profit Pressure and Enterprise Financialization-A Quasi-Natural Experiment Based on Double Difference Model. Sustainability 2022, 14, 711. https://doi.org/10.3390/ su14020711

Academic Editors: Tomasz Kijek, Aleksandra Kowalska, Arkadiusz Kijek and Anna Matras-Bolibok

Received: 11 November 2021 Accepted: 10 December 2021 Published: 10 January 2022

Publisher's Note: MDPI stays neutral with regard to jurisdictional claims in published maps and institutional affiliations.

Copyright: (c) 2022 by the authors. Licensee MDPI, Basel, Switzerland. This article is an open access article distributed under the terms and conditions of the Creative Commons Attribution (CC BY) license (https:// creativecommons.org/licenses/by/ $4.0 /)$.

\begin{abstract}
Based on the urgent need of the real economy to "get away from fictitious to substantial", this paper constructs a quasi-natural experiment based on the margin trading program gradually implemented in China in 2010 and studies the influence of the margin trading program on the financialization level of the target company by using the difference-in-difference method. The results show that, because of the dominant role of financing transactions in margin trading programs in China's capital market, financing transactions drive up the share prices of listed companies, which leads to an excessive easing of the financing constraints of listed companies and short-sighted behavior of executives, which has a significant role in promoting enterprise financialization. Moreover, the driving effect is more significant in state-owned enterprises, enterprises with a high degree of financing constraint, and enterprises with a low degree of marketization. Economic policy uncertainty will restrain the positive effect of margin trading programs on enterprise financialization through information and governance mechanisms. In contrast, the "branding" effect caused by the financial connection of senior executives will intensify the positive relationship between margin trading programs on enterprise financialization levels. When considering the intermediary effect, we find that the margin trading program will result in the optimistic deviation of analysts' earnings forecasts and cause the external profit pressure of enterprises, thus increasing the financialization trend. This study is of great theoretical significance and practical value for evaluating the policy effect of the margin trading program, improving this policy, investigating the influencing factors of enterprise financialization, and promoting the real economy to move from fictitious to substantial.
\end{abstract}

Keywords: margin trading program; enterprise financialization; external earning pressure; economic policy uncertainty; financial connection of senior executives

\section{Introduction}

The margin trading system, also known as the credit trading system, has become mature and become an important securities pricing mechanism in the capital markets of developed countries, such as the United States and those of Europe. Due to the high proportion of retail investors in China's capital market, the imperfect governance mechanism of listed companies, and the relatively limited management experience of financial regulators, the margin trading system started late and is not mature. It has gradually gone through several revisions of "Total prohibition-Regulation revision-The pilot-The Expansion". In 2008, China's State Council executive meeting issued the "regulations on the supervision and administration of securities companies (hereinafter referred to as the regulations)", which marked the margin system formally with laws and regulations. The regulations indicate that margin trading is defined as "the business activities of securities companies lending funds to customers to buy securities or lend Securities for sale, and 
customers depositing corresponding collateral". In 2010, China's stock market formally entered the stage of pilot securities lending and borrowing business; on March 31, the implementing rules for the margin trading pilot reported were selected as margin trading mark 90 blue-chip stocks for the first time. Since 2010, China's stock market has increased the margin target six times; to the end of 2019, a total of 1600 stocks have become margin targets, accounting for more than $50 \%$ of the total number of A-share listed companies. The margin trading system in China is gradually on the right track, but there is a high degree of asymmetry between margin trading and margin trading in the capital market, and the margin trading occupies a dominant position, while the short-selling mechanism is still constrained to a certain extent. At present, research on the economic consequences of the margin lending and short-selling system mainly focuses on market pricing efficiency [1-3] and corporate governance [4,5] and investment decisions [6-8], but the research results are not conclusive, and further exploration is still needed.

In recent years, with the trend of economic globalization and the rapid development of science and technology and financial industries, the financialization of Chinese enterprises has become increasingly apparent, and the economy has shown a trend of transforming from substantial to fictitious $[9,10]$. From the perspective of the resource allocation behavior of enterprises, the proportion of the financial assets in the total assets gradually increases, and enterprises invest more funds in financial assets instead of production and operation activities. From the perspective of corporate earnings, the proportion of non-operating profits gradually increases, and corporate profits are more from investment activities than the enterprise's main business. Based on the analysis of the existing research literature, the analysis of the motivation of enterprise financialization mainly forms the "reservoir" theory [11], the "investment substitution" theory [12], and the "entity intermediary" theory [13]. According to the "reservoir" theory, the characteristics of the high liquidity of financial assets enable them to serve as liquidity reserves of enterprises. When enterprises face high capital pressure, allocating necessary financial assets can help reduce the liquidity risk of enterprises and help develop their main business. The "investment substitution" theory points out that, when the return rate of the main business decreases while the return rate of financial asset investment increases, enterprises tend to increase the proportion of financial asset allocation based on the profit motive. There is a substitution relationship between the main business and financial assets.

On the other hand, the theory of "entity intermediary" holds that, due to the credit rationing behavior of banks, some enterprises will loan funds from banks at a lower interest rate and then transfer them to enterprises with higher financing constraints to earn an interest margin. At present, few pieces of literature consider the causes of enterprise financialization from a macro perspective; it is mainly analyzed from the uncertainties of economic policies and the deregulation of interest rates. The implementation of margin trading system is an important institutional change in the capital market. Whether and how it affects the investment decision of enterprise financial assets is an important issue to be studied. The research conclusion of this paper can provide important reference value for the governance of "getting rid of the virtual to the real" of China's real economy and improving the margin trading system.

The margin lending and short-selling system in China has been expanded six times since the pilot project in 2010. Currently, the target of margin lending and short-selling has increased to 1600 stocks, which provides a data basis for this paper's "quasi-natural experiment". This article selects the A-share listed companies from 2008 to 2019 data using the double difference method to explore the margin trading system that will affect the enterprise financial assets investment decision-making and makes comparisons with Deng and Yan, as well as MacLachlan [14,15]. It is believed that the margin trading system will intensify the degree of enterprise financialization.

The marginal contributions of this paper are as follows: first, starting from the nature of enterprise property rights, degree of financing constraints, and degree of marketization, the paper analyzes whether the implementation of the margin lending and short-selling 
system has heterogeneity in its impact on the level of enterprise financialization, which is helpful to reduce the level of enterprise financialization from the perspective of improving the micro characteristics.

Second, this article found that economic policy uncertainty weakens the margin system financialization of the role of the enterprise. In contrast, the financial relationship of senior executives has a positive regulatory effect on the relationship between margin trading system and enterprise financialization. This conclusion help to consider how to reduce management myopia behavior and prevent the enterprise from "transforming the economy from substantial to fictitious".

Thirdly, according to the earnings forecast data of analysts and the potential earnings data of enterprises, the variable of external earnings pressure of enterprises is constructed, and the function path test is conducted to analyze whether the margin trading programme affect enterprises' financial asset allocation decisions by influencing the external earnings pressure of enterprises.

The fourth contribution is to measure the level of enterprise innovation by enterprise R\&D investment and expand the research on whether margin and short-selling systems will affect the relationship between enterprise financialization and enterprise innovation.

The research results of this paper also explore the influence of the financing mechanism and short-selling mechanism on the financialization of enterprises, which has significant reference value for exploring the policy effect of the margin and short-selling system and the governance of China's real economy from virtual to real.

The rest of this paper is arranged as follows: the second part is the literature review; the third part is the theoretical analysis and research hypothesis; the fourth part is the empirical research design; the fifth part is an empirical test and results and analysis, and the last part is the conclusion and policy suggestions.

\section{Literature Review}

\subsection{Economic Consequences of Margin Trading}

After sorting out the existing literature, it is found that current scholars mainly explore the economic consequences of implementing the margin trading system from the perspectives of stock market pricing efficiency, corporate governance, and investment decision-making. Firstly, in terms of the pricing efficiency of the stock market, Miller [1] first proposed that, due to the differences in investors' understanding of stock-related information, short-selling restrictions will force pessimistic investors to withdraw from the market gradually, and the stock price mainly reflects the expectations of optimistic investors. Therefore, the stock price is overvalued, and the pricing efficiency of the capital market decreases. Hong and Stein [2] found that, if short-selling is not allowed, the negative information of the enterprise will be released to a certain extent, which may eventually lead to the decline in the stock price and even exacerbate the stock price collapse. On the contrary, Allen and Gale [16] and Goldstein and Guembel [17] found through empirical research that, if there is no short-selling restriction, securities lending trading will lead to drastic market fluctuations, thus increasing the risk of stock collapse. Some domestic scholars believe that implementing a margin trading system helps enhance the price discovery function of the capital market, correct the overvaluation of the stock price, and improve the pricing efficiency of the capital market [18,19]. However, Huang [20] and Sun [21] believe that the margin trading system does not improve the pricing efficiency of the capital market but also increases the risk of stock price collapse. Secondly, in terms of corporate governance, the existence of a securities lending system will increase the possibility of short-sellers finding enterprise earnings manipulation to reduce the motivation and behavior of management's earnings management.

A short-selling mechanism has become an important external supervision mechanism to limit enterprise management's financial fraud, but, on the contrary, the existence of a financing mechanism will increase enterprise management's earnings management behavior [4,22]. Facing the challenge of a short-selling mechanism, enterprise management tends 
to reduce the quality of enterprise information disclosure or reduce negative information disclosure, such as reducing the readability of the annual report and adding uncertain words in the annual report, to avoid enterprises becoming short-sellers [5,23]. Finally, in terms of enterprise investment decision-making, Grullon et al. [6] used the quasi-natural experimental method and found that the scale of enterprise capital investment will decline with the gradual release of short-selling constraints in the capital market. Wu and You et al. [24] believed that, if the enterprise management makes wrong investment decisions, investors may short-sell the company's shares so that the short-selling mechanism can have an external supervision effect on the management's over-investment behavior. Chen et al. [25] and Yixin et al. [7] proposed that, since the stock price can reflect the private information owned by investors, the enterprise management may obtain relevant external information of investors by analyzing the stock price to promote enterprise innovation investment. However, He and Tian [8] by analyzing the impact of financing transaction and securities lending transactions on enterprise innovation investment, respectively, found that the former has a negative impact on innovation and the latter has a positive impact on innovation. Due to the high asymmetry between financing transactions and securities lending transactions in China, it is always felt that it limits the innovation and development of enterprises.

\subsection{Influencing Factors of Enterprise Financialization}

The existing literature has explored the influencing factors of enterprise financialization from the macro-economic and micro-enterprise levels. From the macro level, when the economic cycle slows down, the M2 cycle variable is positive, the statutory reserve ratio is high, and the growth rate of the stock index decreases; enterprises will increase the allocation of financial assets. Enterprises hold financial assets mainly as reserve funds, preventing a liquidity crisis [11]. In addition, reducing the tax burden of enterprises can also enable enterprises to reduce the allocation of financial assets. Since corporate governance and enterprise investment behavior will affect the financial status and operating results of enterprises to a great extent, more and more scholars pay attention to relevant research. Enterprise financialization is an important investment behavior of enterprises, and it is particularly important to study its influencing factors [26,27]. From the micro-level, Song and $\mathrm{Lu} \mathrm{[28]} \mathrm{and} \mathrm{Li} \mathrm{et} \mathrm{al.} \mathrm{[29]} \mathrm{found} \mathrm{that} \mathrm{enterprises} \mathrm{with} \mathrm{high} \mathrm{and} \mathrm{low} \mathrm{performance} \mathrm{have} \mathrm{a}$ higher degree of financialization, while enterprises with medium performance have a lower trend of financialization. In addition, if enterprises have less operational risk and banks provide more credit support, enterprise financialization will be significantly improved [30]. Other scholars study the impact on enterprise financialization from the perspective of executive characteristics and believe that executive financial background and financial experience can improve the allocation of financial assets [14,31]. Market competition will also increase enterprises' arbitrage motivation and the tendency of "disenchantment from reality to emptiness" of the real economy. According to the literature review, few scholars explore its impact on financialization from the perspective of margin trading's innovative capital market system.

At present, China's margin trading system is still in the development stage, which is still not perfect compared with developed countries. At this stage, there is no unified conclusion on the research on the relationship between margin trading and enterprise investment, and it mainly focuses on the impact of margin trading on enterprise investment expenditure, investment efficiency, and innovative investment. Whether and how margin trading affects the allocation of enterprise financial assets is less involved, so it is worth further exploration. The macro-level factors affecting enterprise financialization focus on macroeconomic development, economic policy uncertainty, and tax policy. Few scholars discuss how the new capital market system affects the behavior of investors and then the allocation of enterprise financial assets from the perspective of the capital market. The current article on the relationship between the margin trading system and enterprise financialization does not analyze its path of action, nor does it consider whether the 
relationship between the margin trading system and enterprise financialization will change under different economic situations and corporate governance situations. Based on the current situation that financial assets "crowd out" the real economy, resulting in "from substantial to fictitious", this article creatively considers the role channels of the margin trading system influencing enterprise financialization from the perspective of corporate external profit pressure. It explores whether the relationship between the margin trading system and enterprise financialization will be possible when economic policy uncertainty and senior management's finance degree are relatively high. The research conclusion has important practical value for improving China's margin trading system, guiding funds to return to the real economy, and promoting enterprises to "get rid of virtual reality".

\section{Theoretical Analysis and Research Hypothesis}

This section may be divided into subheadings. It should provide a concise and precise description of the experimental results, their interpretation, and the experimental conclusions that can be drawn.

\subsection{Relationship between Margin Trading System and Enterprise Financialization}

As an information communication channel between enterprise investors and management, the stock price of listed companies reflects investors' expectations for the future development of enterprises and will also affect the investment decisions of enterprise management. The margin trading system is essentially a credit transaction with a leverage effect, enabling investors to affect the stock price to a greater extent $[2,18,19]$, more quickly transmit positive or negative information related to enterprises to the capital market, and affect the investment decision-making of the management. When investors get good news about enterprises, they will conduct financing transactions: borrow funds to buy many company shares. Therefore, the management pays more attention to the short-term value of investment projects and increases financial asset investment $[32,33]$ to achieve the purpose of maintaining high stock prices finally. Specifically, the good news of listed companies will push up the company's stock price through the leverage of the financing mechanism. The enterprise management will take opportunistic behavior to maintain the enterprise's short-term performance to boost investor confidence and stabilize the stock price. Nowadays, the deviation between the real economy yield and the financial asset yield makes it important for enterprise management to earn short-term income through financial asset investment at the expense of the enterprise's long-term value [34]. On the other hand, executive compensation is usually related to the company's stock price and performance; the stock price is also an important assessment indicator of the management's reputation during its tenure. When the good news drives the stock price up with the help of the financing mechanism, the enterprise's management will cater to the short-term market sentiment and give up projects with a long investment cycle, increasing financial assets with low long-term value. However, it can quickly cash in earnings and improve the level of enterprise financialization.

However, when there is bad news about listed companies, investors will take securities lending transactions, that is, borrow securities of listed companies and buy securities to repay when the bad news leads to the decline in the stock price to earning the securities price difference. The existing literature holds that the short-selling mechanism of securities lending has a "governance effect", which can deter the enterprise management and reduce the agency problem between the management and shareholders to a certain extent [35]. On the one hand, the securities lending trading mechanism will strengthen the external supervision role of short-sellers on the company's management [24,36]. Suppose the enterprise's management significantly increases the investment ratio of enterprise financial assets to improve personal salary or personal reputation, for example, to obtain short-term performance, resulting in higher risks for the enterprise. In that case, external shortsellers will mine the negative news related to the enterprise and short the company's shares. Therefore, the "deterrent effect" of the securities lending mechanism will urge the 
enterprise management to consider the long-term value of the enterprise, choose highquality investment targets more suitable for the long-term development of the enterprise, and reduce more radical financial asset investment. On the other hand, the securities lending trading mechanism can improve the efficiency of stock pricing, give play to price discovery $[2,18]$, and make compensation contract management more efficient since most of the remuneration of the management of listed companies includes stocks and options to avoid the risk of falling stock prices. The company's management tends to reduce shortsighted behavior and choose a more peaceful strategy to allocate the company's resources to projects that can enhance the enterprise's long-term value, send a positive signal of good operation to the capital market, and avoid becoming the goal of short-selling.

Based on the above analysis, both the financing mechanism and the securities lending mechanism will affect the enterprise's financial asset investment decision through its stock price, but they have the opposite impact on its financialization. Financing and securities lending transactions in China's capital market are highly asymmetric, and the scale of the former far exceeds that of the latter. As the financing and trading mechanism plays a leading role, overall, the margin trading mechanism positively impacts enterprise financialization. This paper puts forward the following hypotheses:

Hypothesis 1 (H1). The implementation of a margin trading system will improve the financialization level of enterprises.

\subsection{The Moderating Effect of Economic Policy Uncertainty and Executive Financial Relevance}

The above analysis shows that the margin trading system will affect the management's investment decision-making behavior by affecting the management's demand to maintain the rising trend of the company's stock price. Economic policy uncertainty will change the risks faced by enterprises and business development, thus affecting the relationship between the margin trading system and enterprise investment decision-making behavior. Le and Zak [37] proposed regulating and controlling macroeconomic development by issuing relevant economic policies. However, due to unclear economic policy expectations, weak policy implementation, or high frequency of policy promulgation, economic policy uncertainty will be caused. Baker et al. [38] constructed an index to measure various countries' economic policy uncertainty index. The index shows that China's economic policy uncertainty has a rising trend after the economic crisis, higher than major developed countries [39]. According to the "reservoir" theory, as a liquidity reserve tool, financial assets can exchange liquidity for enterprises when necessary [40] to prevent bankruptcy risk caused by the rupture of the enterprise capital chain. When the uncertainty of economic policy increases, it will be more challenging to study and judge the future market orientation, which will severely impact the enterprise's business and make it difficult to obtain stable cash flow. At this time, the enterprise management tends to choose to increase the financial asset reserve to prevent the impact of the external environment on the enterprise's business to alleviate the enterprise liquidity crisis [41]. In addition, from the perspective of hedging risk, the increase in economic policy uncertainty will enable enterprises to select forward contracts, option contracts, and other derivative financial assets to achieve the purpose of hedging, which will also increase the trend of enterprise financialization. Therefore, when the margin trading mechanism causes the management's short-sighted behavior and increases the investment in financial assets, the high uncertainty of economic policy will aggravate the enterprise's operation and liquidity risks. The enterprise's management may change the investment strategy and improve financialization to alleviate the liquidity crisis, support the main business, and disperse risks [42]. Therefore, the margin trading system will increase the trend of enterprise financialization, and the uncertainty of economic policy will further aggravate the positive relationship between the two.

However, the rising uncertainty of economic policy may also make it difficult for banks to identify the solvency and credit risk of financing enterprises, reduce the scale of credit capital investment, and increase the degree of financing constraints of enterprises. 
Therefore, enterprises will reduce the allocation of financial assets [43]. In addition, the uncertainty of economic policy means that the financial regulatory policy may change, making the value of financial assets fluctuate significantly to a certain extent and even presenting the risk of difficulty in cashing, resulting in the management taking a more cautious attitude towards financial assets. Moreover, the sharp fluctuation in the price of financial assets will weaken its function as a liquidity reserve and reduce the willingness of enterprises to invest in financial assets. Therefore, when the margin trading system promotes the financing investment behavior, the increase in economic policy uncertainty will lead to the sharp fluctuation of financial asset prices, the decline in liquidity, and the increase in enterprise financing constraints. All this leads to the reduction on the financial asset investment scale; that is, the economic policy uncertainty will have a negative regulatory effect on the relationship between margin trading and enterprise financialization. Therefore, the following competitive hypothesis can be obtained in this paper:

Hypothesis 2a (H2a). The uncertainty of economic policy will aggravate the role of margin trading in promoting financialization.

Hypothesis $\mathbf{2} \mathbf{b}(\mathbf{H} \mathbf{2 b})$. The uncertainty of economic policy will inhibit the promotion of margin trading on the level of financialization.

Executive financial association refers to the fact that senior executives have experience in the financial industry, such as holding relevant positions in commercial banks, securities companies, insurance companies, and fund companies. Hambrick and Mason [44] put forward the "high-level ladder theory", which holds that enterprise managers' work and life experience will affect their cognition and value judgment, change their strategic choices, and result in different business and management decisions. The relevant work experience of senior executives in the financial field enables senior executives to have relevant professional knowledge in the financial industry, making it easier to pay attention to relevant information in the financial field. It will imperceptibly change their business management or investment and financing-related decisions. Specifically, firstly, based on the "brand" theory in biology, executives with financial experience have a clearer understanding of the financial field and the nature of financial assets and have a higher tolerance for financial investment risks. Therefore, they will tend to invest in financial assets. Secondly, executives with higher financial relevance have more vital investment timing and capital operation ability. In order to improve personal salary and realize selfworth, they tend to increase the proportion of financial asset investment [31]. Thirdly, the management with high financial relevance knows more about financial institutions and can establish close contact with them, which helps alleviate the information asymmetry between enterprises and financial institutions and reduce enterprise financing constraints [45] to increase enterprise financial asset investment.

According to the above, implementing the margin trading system will improve the efficiency of stock pricing, and the enterprise management will adopt short-sighted strategies to increase the financial level of the enterprise to stabilize the stock price. Compared with enterprises with low financial relevance of executives, if the financial relevance of executives is high, they will use their professional knowledge and resources in the financial field to further increase the allocation of financial assets; that is, the degree of financial relevance of executives has a positive regulatory effect on the relationship between margin trading system and enterprise financialization. Therefore, this paper puts forward the following hypothesis:

Hypothesis $3 \mathbf{~ ( H 3 ) . ~ T h e ~ d e g r e e ~ o f ~ f i n a n c i a l ~ r e l e v a n c e ~ o f ~ s e n i o r ~ e x e c u t i v e s ~ w i l l ~ a g g r a v a t e ~ t h e ~}$ promotion of margin trading on the level of financialization. 


\subsection{The Intermediary Role of External Profit Pressure of Enterprise}

Securities analysts have financial expertise, specific resources, and contacts in the financial field, can collect more information about the operation and development of listed companies than ordinary investors, and release relevant earnings forecasts and investment rating reports to the capital market [46]. This may change the expected return of investors, further affect the investment decisions of enterprise management, and form external profit pressure on management. Investors will carry out financing transactions when enterprises have good news, affecting stock prices. However, according to the existing research, the short-selling mechanism plays a minimal role when the financing transaction is in full swing. The margin trading system not only does not improve the accuracy of analysts' earnings forecast but, on the contrary, analysts will also increase the possibility of becoming a star analyst and improve the turnover rate of relevant stocks by issuing more optimistic earnings forecasts [20]. Analysts release more optimistic profit forecasts to the market, which will damage the stock pricing efficiency to a certain extent, increase investors' expectations for improving enterprise stock price, and form the external profit pressure of enterprise management. At this time, corporate management will be more conservative in their main business investment in pursuit of profit and pursue financial assets that can bring short-term profits and are easier to manipulate earnings, resulting in a "crowding-out effect" on the real economy, leading to an increase in the trend of corporate financialization [47,48], thus forming a transmission channel of "margin trading system-external profit pressure-enterprise financialization". Therefore, this paper puts forward the following hypothesis:

Hypothesis 4 (H4). The external profit pressure of enterprises plays an intermediary role in the relationship between implementing the margin trading system and enterprise financialization. The margin trading system will further increase the trend of enterprise financialization by increasing the external profit pressure of enterprises.

\section{Model Establishment}

\subsection{Sample Data Selection}

This paper uses 23,498 observations of A-share listed companies from 2008 to 2019 as the research sample. Because this paper studies the impact of the margin trading system on enterprise financialization, it excludes companies in the financial industry and real estate industry, listed company under special treatment, listed company under particular transferring, and many companies with missing values. Our sample consists of 3414 firms, of which 1575 have been included in the target of margin trading program in place in 2019. These 1575 firms comprise our treatment sample. The remaining firms not included in place during our sample period are the control sample. In addition, to avoid the influence of extreme values, the continuous variables used are reduced by $1 \%$ up and down. This paper's macro and enterprise microdata are from the wind and CSMAR databases.

\subsection{Model Design}

The margin trading system provides the research conditions of a "quasi-natural experiment" for this problem. According to the results of Hausman's test, this paper should use a fixed-effects model to test. Drawing on Wu and You et al. [3,24], this paper uses the following double difference DID model to test the impact of the implementation of margin trading system on the level of enterprise financialization and designs the following model:

$$
\text { Finance }_{i, t}=\beta_{0}+\beta_{1} \text { List }_{i}+\beta_{2} \text { PostList }_{i, t}+\beta_{3} C V s_{i, t}+y_{t}+a_{i}+\epsilon_{i, t}
$$

In the model, subscript $i$ refers to the individual enterprise, $t$ refers to the year, and Finance refers to the degree of enterprise financialization. Based on Kliman and Williams efficiency [49], Song and $\mathrm{Lu}$ [28], and Knoerich and $\mathrm{Xu}$ [50], this paper uses the proportion of enterprise financial assets in the total assets to measure the level of enterprise gold 
melting in which financial assets include enterprise transactional financial assets, derivative financial assets loans, and advances, available for sale financial assets, held to maturity investment, long-term equity investment, investment real estate, and purchase of resale financial assets. After implementing accounting standards for Business Enterprises No. 22-recognition and measurement of financial instruments in 2018, financial assets also include financial assets measured at amortized cost. There are three types of financial assets measured at fair value with changes included in other comprehensive income and financial assets measured at fair value with changes included in current profit and loss. List and PostList are the proxy variables of the margin trading system as previously defined. $C V s_{i, t}$ is a company k-level control variable that changes with time; $y_{t}$ is a time level effect; $a_{i}$ is a company fixed effect, which controls individual-level characteristics that do not change with time to reduce the bias of omitted variables; $\epsilon_{i, t}$ means residual term. The coefficient of PostList $\beta_{2}$ refers to the difference between the change of enterprise financialization degree before and after the enterprise is included in the list of financing and securities lending targets and that of other companies. If coefficient $\beta_{2}$ is significantly positive, it indicates that the implementation of the margin trading system has increased the trend of enterprise financialization; otherwise, it indicates that margin trading has reduced the level of financialization.

Referring to He et al. [30] and Deng and Yan [14], this paper controls the following variables in Equation (1): enterprise size, which is measured by the natural logarithm of total assets at the end of the period; enterprise profitability ROA is measured by the rate of return on total assets of the enterprise; enterprise financial leverage is measured by enterprise equity multiplier; the equity concentration of the enterprise is Top10, which is measured by the shareholding proportion of the top ten shareholders of the enterprise; the turnover rate of enterprise assets is measured by the turnover rate of enterprise total assets; the enterprise inventory level is measured by the proportion of the enterprise's ending inventory in the total assets; TobinQ, the enterprise growth opportunity variable, is measured by TobinQ value, that is, the ratio of enterprise market value to asset replacement cost; the cash flow status of the enterprise is $\mathrm{CFO}$, which is measured by the proportion of the net operating cash flow of the enterprise; capital expenditure CAP is measured by the proportion of cash paid for the construction of fixed assets, intangible assets, and other long-term assets in the total assets at the end of the period. The specific variable definitions are shown in Table 1.

This paper further classifies the samples according to the nature of property rights, the degree of financing constraints, and marketization tests the impact of the implementation of the margin trading system on the level of enterprise financialization and investigates whether there is heterogeneity between different types of enterprises.

For the regulatory role of economic policy uncertainty, this paper establishes a model (2) to investigate whether economic policy uncertainty has a regulatory effect on the relationship between margin trading and enterprise financialization. This paper uses Baker et al. [38] and Pan et al. [51] to use the data published by Stanford University and the University of Chicago in the development of the economic policy uncertainty index website (www.policyuncertainty.com, accessed on 10 November 2021) and select the economic policy uncertainty index calculated according to the Chinese mainland newspaper. Divide the monthly average of the index by 100 as the proxy variable of China's economic policy uncertainty (CNEPU). According to hypothesis $\mathrm{H} 2$, if the uncertainty of economic policy promotes the margin trading system's positive effect on enterprise financialization and produces a positive regulatory effect, the coefficient PostList $\times$ CNEPU symbol of the interaction term predicted in this paper is significantly positive. If economic policy uncertainty inhibits the promotion of the margin trading system on enterprise financialization, the coefficient sign of the predicted interaction term PostList $\times$ CNEPU is significantly negative.

Finance $_{i, t}=\beta_{0}+\beta_{1}$ List $_{i}+\beta_{2}$ Post List $_{i, t}+\beta_{3}$ CNEPU $_{t}+\beta_{4}$ Post List $_{i, t} \times C N E P U_{t}+\beta_{5} C V s_{i, t}+y_{t}+a_{i}+\epsilon_{i, t}$ 
Table 1. The variable definition.

\begin{tabular}{|c|c|c|}
\hline Variable Name & Variable Definition & Construction Method \\
\hline Finance & Enterprise financialization & The proportion of enterprise financial assets in total assets \\
\hline List & Margin trading & $\begin{array}{l}\text { If the company is included in the margin trading list during the } \\
\text { sample period, the sample value of the company is } 1 \text {; otherwise, } \\
\text { the value is } 0\end{array}$ \\
\hline Post & & $\begin{array}{l}\text { The value is } 1 \text { in the year after the company enters the margin } \\
\text { trading list; otherwise, the value is } 0\end{array}$ \\
\hline PostList & & $\begin{array}{l}\text { In the year after the company is included in the subject matter of } \\
\text { margin trading, the value is } 1 \text {; otherwise, the value is } 0\end{array}$ \\
\hline Size & Enterprise-scale & Natural logarithm of total assets at the end of the period \\
\hline $\mathrm{ROA}$ & Enterprise profitability & Return on total assets, i.e., net profit/total assets \\
\hline Leverage & Enterprise leverage level & $\begin{array}{l}\text { Equity multiplier, i.e., total assets/owner's equity of the } \\
\text { enterprise }\end{array}$ \\
\hline Top10 & Ownership concentration & The shareholding ratio of the top ten shareholders \\
\hline Turnover & Asset management capability & $\begin{array}{l}\text { Total asset turnover rate, i.e., sales revenue } / 0.5 \times(\text { total assets at } \\
\text { the beginning of the period }+ \text { total assets at the end of the period })\end{array}$ \\
\hline Inventory & Enterprise inventory level & Inventory/total assets \\
\hline TobinQ & Business growth opportunities & Enterprise market value/total assets \\
\hline $\mathrm{CFO}$ & The proportion of operating cash flow & Net operating cash flow/total assets \\
\hline CAP & The proportion of capital expenditure scale & $\begin{array}{l}\text { Cash/total assets paid by the enterprise for the construction of } \\
\text { fixed assets, intangible assets, and other long-term assets }\end{array}$ \\
\hline CNEPU & Economic policy uncertainty & $\begin{array}{l}\text { Economic policy uncertainty index compiled from Chinese } \\
\text { mainland newspaper }\end{array}$ \\
\hline Finbac & Executive financial relevance & $\begin{array}{l}\text { Number of executives with financial connections/total number of } \\
\text { executives }\end{array}$ \\
\hline GAP & Profit pressure & $\begin{array}{l}\text { The difference between the average of analysts' earnings per } \\
\text { share forecast and the potential earnings per share of the } \\
\text { enterprise is described below }\end{array}$ \\
\hline
\end{tabular}

In order to explore the regulatory effect of executive financial relevance on the relationship between the implementation of the margin trading system and enterprise financialization, this paper constructs the following model (3) for the empirical test. FinBac is the proxy variable of executives' financial relevance in the model. According to Du et al. [45] and Yuewen and $\mathrm{Lu}$ [31], this paper regards executives who have worked in the financial industry or are working part-time in the financial industry as executives with financial relevance and measures executives' financial relevance by the proportion of executives with financial background. Among them, senior executives include the chairman, general manager, chief financial officer, and directors who can impact the enterprise's production and operation and investment management decisions. According to hypothesis H3, the executive financial association has a positive regulatory effect on the relationship between the implementation of margin trading and enterprise financialization. Therefore, this paper predicts that the coefficient PostList $\times$ FinBac sign of the interaction term should be significantly positive.

Finance $_{i, t}=\beta_{0}+\beta_{1}$ List $_{i}+\beta_{2}$ PostList $_{i, t}+\beta_{3}$ FinBac $_{i, t}+\beta_{4}$ PostList $_{i, t} \times$ FinBac $_{i, t}+\beta_{5}$ CV $s_{i, t}+y_{t}+a_{i}+\epsilon_{i, t}$

According to Wen and Ye [52], this paper uses a progressive model to test whether implementing a margin trading system will affect enterprise financialization by increasing the external profit pressure of enterprises. The progressive model is divided into the following three steps: the first step is to test the impact of margin trading on the financial level of enterprises, which is the same as the model (1), and is omitted here; The second step is to build a model (4) to test whether the implementation of margin trading will increase the external profit pressure of the enterprise. The third step is to build a model (5) and take the implementation of margin trading PostList and external profit pressure gap as independent variables into the model to investigate their impact on the level of enterprise 
financialization. Referring to Zhang and Gimeno [47] and Chai et al. [53], this paper uses the change rate of earnings per share in $\mathrm{T}-1$ and the excess rate of return in $t$ to predict the change rate of earnings per share in $\mathrm{T}$, calculates the expected value of earnings per share change according to the regression coefficient, and further calculates the potential earnings per share. Finally, the difference between the average value of analysts' earnings per share forecast and potential earnings per share is used as the proxy variable of external earnings pressure GAP.

$$
\begin{gathered}
G A P_{i, t}=\beta_{0}+\beta_{1} \text { List }_{i}+\beta_{2} \text { PostList }_{i, t}+\beta_{3} \text { CVs } s_{i, t}+y_{t}+a_{i}+\epsilon_{i, t} \\
\text { Finance }_{i, t}=\beta_{0}+\beta_{1} \text { List }_{i}+\beta_{2} \text { PostList }_{i, t}+\beta_{3} G A P_{i, t}+\beta_{4} C V s_{i, t}+y_{t}+a_{i}+\epsilon_{i, t}
\end{gathered}
$$

\subsection{Main Descriptive Statistics}

This paper makes descriptive statistics on the main variables. The results are shown in Table 2. The mean value of the proportion of enterprise financial assets in total assets is 0.0743 , the median is 0.0351 , and the standard deviation is 0.1023 , which is consistent with the existing literature [54], indicating that the degree of financialization of Chinese enterprises is high. There is a significant difference between enterprises. The average value of list is 0.585 , indicating that an average of $58.5 \%$ of the samples is the subject stocks of margin trading during the sample period. Due to the sixth expansion in 2019, this proportion is higher than in the existing literature. Other control variables' descriptive statistical results are consistent with the existing literature, not repeated here. According to the correlation coefficient table (Pearson coefficient and Spearman coefficient, which are not listed in the article's length), PostList and finance are significantly positively correlated, which preliminarily shows that implementing the margin trading system will implement significantly improve the financialization level of enterprises.

Table 2. Descriptive statistics.

\begin{tabular}{ccccccc}
\hline Variable & $\begin{array}{c}\text { Observed } \\
\text { Value }\end{array}$ & $\begin{array}{c}\text { Mean } \\
\text { Value }\end{array}$ & Median & $\begin{array}{c}\text { Standard } \\
\text { Deviation }\end{array}$ & Minimum & Maximum \\
\hline Finance & 23,498 & 0.074 & 0.035 & 0.102 & 0 & 0.541 \\
List & 23,498 & 0.585 & 1 & 0.493 & 0 & 1 \\
PostList & 23,498 & 0.271 & 0 & 0.445 & 0 & 1 \\
Size & 23,498 & 12.992 & 12.820 & 1.292 & 9.187 & 16.640 \\
ROA & 23,498 & 0.0456 & 0.040 & 0.059 & -0.176 & 0.355 \\
Leverage & 23,498 & 1.166 & 0.769 & 1.228 & 0.057 & 7.034 \\
Top10 & 23,498 & 0.584 & 0.592 & 0.155 & 0.229 & 0.961 \\
Turnover & 23,498 & 0.682 & 0.571 & 0.476 & 0.076 & 2.818 \\
Inventory & 23,498 & 0.154 & 0.117 & 0.144 & 0.0004 & 0.706 \\
TobinQ & 23,498 & 2.001 & 1.581 & 1.280 & 0.885 & 8.612 \\
CFO & 23,498 & 0.047 & 0.046 & 0.072 & -0.16945 & 0.331 \\
CAP & 23,498 & 0.050 & 0.036 & 0.048 & 0.0003 & 0.274 \\
SOE & 23,498 & 0.448 & 0 & 0.497 & 0 & 1 \\
CNEPU & 23,498 & 3.189 & 2.444 & 2.165 & 0.989 & 7.919 \\
Finbac & 23,498 & 0.075 & 0.053 & 0.087 & 0 & 0.400 \\
Analyst & 23,498 & 1.543 & 1.609 & 1.170 & 0 & 3.664 \\
GAP & 14,700 & -0.581 & -0.356 & 1.025 & -5.357 & 1.501 \\
\hline
\end{tabular}

\section{Results and Discussion}

5.1. Basic Empirical Test Results: The Impact of Margin Trading System on the Level of Enterprise Financialization

Table 3 shows the empirical test results of the impact of the margin trading system on the level of enterprise financialization. Column (1) is the estimated result of the whole sample, and the coefficient of PostList is 0.002 , which is significant at the significance level of $10 \%$, indicating that the margin trading system will promote enterprises to increase the proportion of financial asset allocation. Hypothesis $\mathrm{H} 1$ of this paper is verified. This shows 
that, under the precarious situation of China's margin trading system, the proportion of margin trading is much higher than that of margin trading. The margin trading will raise the company's stock price, urge the enterprise management to take short-sighted behavior to maintain the stock price and their salary and reputation, increase the investment in financial assets, and enhance the trend of enterprise financialization.

Table 3. The impact of margin trading system on enterprise financialization level and heterogeneity test.

\begin{tabular}{|c|c|c|c|c|c|c|c|}
\hline & (1) & (2) & (3) & (4) & (5) & (6) & (7) \\
\hline & Full Sample & $\begin{array}{c}\text { State } \\
\text { Enterprise }\end{array}$ & $\begin{array}{l}\text { Non-State } \\
\text { Enterprises }\end{array}$ & $\begin{array}{c}\text { Group with } \\
\text { High } \\
\text { Financing } \\
\text { Constraints }\end{array}$ & $\begin{array}{c}\text { Group } \\
\text { with Low } \\
\text { Financing } \\
\text { Constraints }\end{array}$ & $\begin{array}{c}\text { High } \\
\text { Marketization } \\
\text { Group }\end{array}$ & $\begin{array}{c}\text { Low } \\
\text { Marketization } \\
\text { Group }\end{array}$ \\
\hline List & $\begin{array}{l}-0.001 \\
(-0.61)\end{array}$ & $\begin{array}{l}-0.003 \\
(-1.21)\end{array}$ & $\begin{array}{l}0.001 \\
(0.56)\end{array}$ & $\begin{array}{c}-0.004^{* *} \\
(-2.27)\end{array}$ & $\begin{array}{c}0.007^{* * *} \\
(2.79)\end{array}$ & $\begin{array}{l}-0.000 \\
(-0.23)\end{array}$ & $\begin{array}{l}-0.002 \\
(-1.01)\end{array}$ \\
\hline PostList & $\begin{array}{c}0.002 * \\
(1.68)\end{array}$ & $\begin{array}{c}0.004^{* *} \\
(2.18)\end{array}$ & $\begin{array}{l}0.003 \\
(1.47)\end{array}$ & $\begin{array}{c}0.003 * \\
(1.70)\end{array}$ & $\begin{array}{l}0.003 \\
(1.09)\end{array}$ & $\begin{array}{l}-0.000 \\
(-0.06)\end{array}$ & $\begin{array}{c}0.005^{* *} \\
(2.44)\end{array}$ \\
\hline Size & $\begin{array}{c}-0.009 * * * \\
(-8.84)\end{array}$ & $\begin{array}{c}-0.014^{* * *} \\
(-9.50)\end{array}$ & $\begin{array}{c}-0.012 \text { *** } \\
(-7.50)\end{array}$ & $\begin{array}{c}-0.014^{* * *} \\
(-9.54)\end{array}$ & $\begin{array}{l}-0.000 \\
(-0.18)\end{array}$ & $\begin{array}{c}-0.007^{* * *} \\
(-4.40)\end{array}$ & $\begin{array}{c}-0.011^{* * *} \\
(-7.57)\end{array}$ \\
\hline ROA & $\begin{array}{l}-0.015 \\
(-1.55)\end{array}$ & $\begin{array}{l}0.014 \\
(0.95)\end{array}$ & $\begin{array}{l}-0.014 \\
(-1.01)\end{array}$ & $\begin{array}{l}0.009 \\
(0.76)\end{array}$ & $\begin{array}{c}-0.074^{* * *} \\
(-4.37)\end{array}$ & $\begin{array}{l}-0.009 \\
(-0.61)\end{array}$ & $\begin{array}{c}-0.025 * \\
(-1.85)\end{array}$ \\
\hline Leverage & $\begin{array}{c}-0.004^{* * * *} \\
(-5.89)\end{array}$ & $\begin{array}{c}-0.004^{* * *} \\
(-5.77)\end{array}$ & $\begin{array}{c}-0.002^{* *} \\
(-2.09)\end{array}$ & $\begin{array}{c}-0.005^{* * *} \\
(-6.09)\end{array}$ & $\begin{array}{c}-0.003^{* * *} \\
(-2.88)\end{array}$ & $\begin{array}{c}-0.006^{* * *} \\
(-5.80)\end{array}$ & $\begin{array}{c}-0.002 * * * \\
(-3.08)\end{array}$ \\
\hline Top10 & $\begin{array}{c}-0.070^{* * *} \\
(-12.71)\end{array}$ & $\begin{array}{c}-0.025^{* * *} \\
(-3.20)\end{array}$ & $\begin{array}{c}-0.074^{* * *} \\
(-9.24)\end{array}$ & $\begin{array}{c}-0.071^{* * *} \\
(-10.29)\end{array}$ & $\begin{array}{c}-0.054^{* * *} \\
(-5.46)\end{array}$ & $\begin{array}{c}-0.092 * * * \\
(-11.03)\end{array}$ & $\begin{array}{c}-0.036^{* * *} \\
(-4.75)\end{array}$ \\
\hline Turnover & $\begin{array}{c}-0.023^{* * *} \\
(-11.60)\end{array}$ & $\begin{array}{c}-0.022 * * * \\
(-8.99)\end{array}$ & $\begin{array}{c}-0.028^{* * *} \\
(-8.82)\end{array}$ & $\begin{array}{c}-0.028^{* * *} \\
(-11.02)\end{array}$ & $\begin{array}{c}-0.016^{* * *} \\
(-4.53)\end{array}$ & $\begin{array}{c}-0.026^{* * *} \\
(-8.59)\end{array}$ & $\begin{array}{c}-0.021 * * * \\
(-7.51)\end{array}$ \\
\hline Inventory & $\begin{array}{c}-0.127^{* * * *} \\
(-18.85)\end{array}$ & $\begin{array}{c}-0.122 * * * \\
(-13.90)\end{array}$ & $\begin{array}{c}-0.127^{* * *} \\
(-12.76)\end{array}$ & $\begin{array}{c}-0.142^{* * *} \\
(-17.24)\end{array}$ & $\begin{array}{c}-0.117^{* * *} \\
(-9.49)\end{array}$ & $\begin{array}{c}-0.144^{* * *} \\
(-14.94)\end{array}$ & $\begin{array}{c}-0.086^{* * * *} \\
(-8.87)\end{array}$ \\
\hline TobinQ & $\begin{array}{c}0.004^{* * *} \\
(8.09)\end{array}$ & $\begin{array}{l}0.001 \\
(1.62)\end{array}$ & $\begin{array}{c}0.005^{* * *} \\
(7.08)\end{array}$ & $\begin{array}{c}0.003^{* * *} \\
(4.62)\end{array}$ & $\begin{array}{c}0.004^{* * *} \\
(4.52)\end{array}$ & $\begin{array}{c}0.004^{* * *} \\
(6.09)\end{array}$ & $\begin{array}{c}0.003^{* * *} \\
(4.35)\end{array}$ \\
\hline CFO & $\begin{array}{c}-0.027^{* * * *} \\
(-3.82)\end{array}$ & $\begin{array}{c}-0.039^{* * *} \\
(-4.18)\end{array}$ & $\begin{array}{c}-0.026^{* * *} \\
(-2.58)\end{array}$ & $\begin{array}{c}-0.021^{* *} \\
(-2.47)\end{array}$ & $\begin{array}{l}-0.019 \\
(-1.62)\end{array}$ & $\begin{array}{c}-0.025^{* *} \\
(-2.45)\end{array}$ & $\begin{array}{l}-0.016 \\
(-1.63)\end{array}$ \\
\hline CAP & $\begin{array}{c}-0.116^{* * *} \\
(-10.32)\end{array}$ & $\begin{array}{c}-0.126^{* * *} \\
(-8.32)\end{array}$ & $\begin{array}{c}-0.100^{* * *} \\
(-6.18)\end{array}$ & $\begin{array}{c}-0.104^{* * *} \\
(-7.25)\end{array}$ & $\begin{array}{c}-0.087^{* * *} \\
(-4.86)\end{array}$ & $\begin{array}{c}-0.122 * * * \\
(-7.32)\end{array}$ & $\begin{array}{c}-0.094^{* * *} \\
(-6.25)\end{array}$ \\
\hline Year & Yes & Yes & Yes & Yes & Yes & Yes & Yes \\
\hline Individual & Yes & Yes & Yes & Yes & Yes & Yes & Yes \\
\hline Constant & $\begin{array}{c}0.267^{* * *} \\
(20.81)\end{array}$ & $\begin{array}{c}0.318^{* * *} \\
(17.82)\end{array}$ & $\begin{array}{c}0.281^{* * *} \\
(15.09)\end{array}$ & $\begin{array}{c}0.333^{* * *} \\
(19.10)\end{array}$ & $\begin{array}{c}0.122 * * * \\
(5.54)\end{array}$ & $\begin{array}{c}0.266^{* * *} \\
(13.17)\end{array}$ & $\begin{array}{c}0.249 * * * \\
(14.58)\end{array}$ \\
\hline $\mathrm{N}$ & 23,498 & 10,523 & 12,975 & 14,546 & 8952 & 12,587 & 10,911 \\
\hline $\mathrm{R}^{2}$ & 0.102 & 0.077 & 0.135 & 0.104 & 0.106 & 0.115 & 0.080 \\
\hline
\end{tabular}

Note: ${ }^{* * *}, * *, *$ indicate, respectively, significant at the level of $1 \%, 5 \%$, and $10 \%$. T value is in parentheses.

Columns (2) and (3), respectively, show the relationship between the margin trading system and enterprise financialization in the subsamples of state-owned and non-stateowned enterprises. The results show that, in the subsamples of state-owned enterprises, the PostList coefficient is 0.004 , more significant than the PostList coefficient in the whole sample and is significant at the significance level of $5 \%$; for the subsamples of non-stateowned enterprises, the PostList coefficient is still positive. However, it is not significant, indicating that the impact of the margin trading system on the financialization level of enterprises is heterogeneous in the nature of property rights: the margin trading system significantly promotes the financialization level of state-owned enterprises. However, it has no significant impact on the financialization level of non-state-owned enterprises. The reason is that, compared with non-state-owned enterprises, most of China's stateowned enterprises have the problem of owner vacancy, the owner's supervision over the management's investment decision is more limited, and the management of state-owned enterprises has higher demands for job promotion and on-the-job consumption. Therefore, 
when the implementation of a margin trading system leads to the rise of enterprise stock price, the management of state-owned enterprises has more motivation to increase the proportion of financial asset allocation to improve short-term performance, and the weak owner supervision also provides conditions for the management to take short-sighted behavior, which is an important reason for the increase in financialization.

Columns (4) and (5) divide the samples into a high financing constraint group and low financing constraint group according to the degree of financing constraint and test the impact of the margin trading system on enterprise financialization, respectively. As for the degree of financing constraints, this paper uses Hadlock and Pierce [55] for reference and uses the SA index to measure the degree of financing constraints, where size is the logarithm of total assets (in millions of yuan) and age is the number of years of enterprise establishment. If the natural logarithm of the absolute value of the SA index is higher than the industry median, it is classified as a high degree of financing constraints group; otherwise, it is classified as a low degree of financing constraints group. According to Table 2, for the group with high financing constraints, the coefficient of PostList is positive and significant at the significance level of $10 \%$, while, for the group with low financing constraints, the coefficient of PostList is positive but not significant. This shows that the promotion effect of the margin trading system on enterprise financialization only exists in the group with high financing constraints, mainly because the dominant financing mechanism leads to the rise of the enterprise stock price. The management is motivated to maintain the company's stock price and salary. Currently, if the enterprise has high financing constraints, on the one hand, the management hopes to maintain the stock price by improving the short-term performance. On the other hand, it is also hoped that the financing constraints of enterprises can be alleviated by increasing the performance, so it is more inclined to improve the proportion of enterprise financial asset allocation and increase the level of enterprise financialization.

Columns (6) and (7) stem from the China marketization index prepared by Wang, Fan et al. [56], divide the samples into a high marketization degree group and low marketization degree group according to whether the marketization index of the province where the enterprise is registered is higher than the industry median, and test the impact of the margin trading system on the financialization level of the two groups of sample enterprises, respectively. The results show that, in the low marketization group, the coefficient of PostList is 0.005 and significant at the significance level of $5 \%$, while, in the high marketization group, the coefficient is positive but not significant. It shows that the influence of the margin trading system on the financial level of enterprises is different among enterprises with different degrees of marketization: the margin trading system has no significant impact on the financial level of enterprises in areas with higher degrees of marketization. However, it has a significant role in promoting the financial level of enterprises in areas with lower degrees of marketization.

\subsection{Test on the Moderating Effect of the Relationship between Economic Policy Uncertainty and Executive Finance}

This paper adds the interaction term between margin trading PostList and economic policy uncertainty CNEPU to the benchmark model to test the regulatory effect of economic policy uncertainty on the relationship between the margin trading system and enterprise financialization. The empirical test results are shown in columns (1) and (2) of Table 4. The margin trading system will promote the level of enterprise financialization, and the coefficient of the interactive term PostList $\times$ CNEPU is -0.001 , which is significant at the significance level of $1 \%$. This indicates that economic policy uncertainty has a negative regulatory effect on the relationship between the margin trading system and enterprise financialization; that is, economic policy uncertainty will inhibit the promotion of the margin trading system on enterprise financialization. The uncertainty of economic policy leads to the sharp fluctuation of the price of financial assets, resulting in a decline in the liquidity of financial assets, making them unsuitable for being used as liquidity reserves, while the uncertainty of economic policy also leads to an increase in enterprise financing 
constraints and more difficulties in obtaining bank credit funds. Therefore, it will weaken the positive effect of the margin trading system on the level of enterprise financialization. Hypothesis $\mathrm{H} 2 \mathrm{~b}$ is verified.

Table 4. The moderating effect of economic policy uncertainty and executive financial correlation.

\begin{tabular}{|c|c|c|c|}
\hline & (1) & (2) & (3) \\
\hline & $\begin{array}{l}\text { Benchmark } \\
\text { Regression }\end{array}$ & $\begin{array}{c}\text { Adjustment Effect of } \\
\text { Economic Policy Uncertainty }\end{array}$ & $\begin{array}{l}\text { Regulation Effect of } \\
\text { Executive Financial Relevance }\end{array}$ \\
\hline List & $\begin{array}{l}-0.001 \\
(-0.61)\end{array}$ & $\begin{array}{l}-0.001 \\
(-0.58)\end{array}$ & $\begin{array}{l}-0.001 \\
(-0.64)\end{array}$ \\
\hline PostList & $\begin{array}{l}0.002 * \\
(1.68)\end{array}$ & $\begin{array}{l}0.008^{* * * *} \\
(3.66)\end{array}$ & $\begin{array}{l}-0.002 \\
(-0.90)\end{array}$ \\
\hline CNEPU & & $\begin{array}{c}0.006^{* * *} \\
(12.76)\end{array}$ & \\
\hline PostList $\times$ CNEPU & & $\begin{array}{l}-0.001^{* * * *} \\
(-3.51)\end{array}$ & \\
\hline Finbac & & & $\begin{array}{l}-0.003 \\
(-0.37)\end{array}$ \\
\hline PostList $\times$ Finbac & & & $\begin{array}{c}0.053^{* * *} \\
(4.58)\end{array}$ \\
\hline Size & $\begin{array}{l}-0.009 * * * \\
(-8.84)\end{array}$ & $\begin{array}{l}-0.009 * * * \\
(-8.99)\end{array}$ & $\begin{array}{l}-0.009 * * * \\
(-8.97)\end{array}$ \\
\hline ROA & $\begin{array}{l}-0.015 \\
(-1.55)\end{array}$ & $\begin{array}{l}-0.015 \\
(-1.54)\end{array}$ & $\begin{array}{l}-0.015 \\
(-1.52)\end{array}$ \\
\hline Leverage & $\begin{array}{l}-0.004^{* * * *} \\
(-5.89)\end{array}$ & $\begin{array}{l}-0.004^{* * * *} \\
(-5.88)\end{array}$ & $\begin{array}{l}-0.004^{* * *} \\
(-5.93)\end{array}$ \\
\hline Top10 & $\begin{array}{l}-0.070 * * * \\
(-12.71)\end{array}$ & $\begin{array}{l}-0.068^{* * *} \\
(-12.38)\end{array}$ & $\begin{array}{l}-0.070 * * * \\
(-12.76)\end{array}$ \\
\hline Turnover & $\begin{array}{l}-0.023 * * * \\
(-11.60)\end{array}$ & $\begin{array}{l}-0.023 * * * \\
(-11.67)\end{array}$ & $\begin{array}{l}-0.023 * * * \\
(-11.68)\end{array}$ \\
\hline Inventory & $\begin{array}{l}-0.127^{* * *} \\
(-18.85)\end{array}$ & $\begin{array}{l}-0.127^{* * *} \\
(-18.86)\end{array}$ & $\begin{array}{l}-0.126^{* * *} \\
(-18.81)\end{array}$ \\
\hline TobinQ & $\begin{array}{c}0.004^{* * *} \\
(8.09)\end{array}$ & $\begin{array}{c}0.004^{* * *} \\
(8.06)\end{array}$ & $\begin{array}{c}0.004^{* * *} \\
(8.04)\end{array}$ \\
\hline $\mathrm{CFO}$ & $\begin{array}{l}-0.027^{* * *} \\
(-3.82)\end{array}$ & $\begin{array}{l}-0.027^{* * *} \\
(-3.80)\end{array}$ & $\begin{array}{l}-0.027^{* * *} \\
(-3.81)\end{array}$ \\
\hline CAP & $\begin{array}{l}-0.116^{* * *} \\
(-10.32)\end{array}$ & $\begin{array}{l}-0.116^{* * *} \\
(-10.32)\end{array}$ & $\begin{array}{l}-0.116^{* * *} \\
(-10.36)\end{array}$ \\
\hline Year & Yes & Yes & Yes \\
\hline Individual & Yes & Yes & Yes \\
\hline Constant & $\begin{array}{c}0.267^{* * *} \\
(20.81)\end{array}$ & $\begin{array}{c}0.257^{* * *} \\
(20.48)\end{array}$ & $\begin{array}{c}0.270 * * * \\
(20.96)\end{array}$ \\
\hline $\mathrm{N}$ & 23,498 & 23,498 & 23,498 \\
\hline $\mathrm{R}^{2}$ & 0.102 & 0.102 & 0.103 \\
\hline
\end{tabular}

Note: ${ }^{* * *},{ }^{*}$ indicate, respectively, significant at the level of $1 \%$ and $10 \%$. T value is in parentheses.

Hypothesis $\mathrm{H} 3$ proposes that, when there is a financial correlation among executives, the promotion effect of margin trading on enterprise financialization will increase. This paper further introduces executive financial correlation variables into the benchmark model to investigate the regulatory effect of executive financial correlation. The regression results are shown in columns (1) and (3). It can be seen from column (3) that the coefficient of the interactive term PostList $\times$ FinBac is 0.053 and is significant at the significance level of $1 \%$, indicating that, based on the promotion of the financialization level by the margin trading system, the executives have financial relevance, which can further improve the promotion of the margin trading on the financialization level. Hypothesis $\mathrm{H} 3$ of this paper is tenable. The test results show that margin trading can promote the improvement of enterprise financialization levels. Suppose enterprise executives have financial connections according to the "brand theory". In that case, enterprise executives are more familiar with 
financial assets, have higher risk-taking ability, and are more willing to use their own financial-related professional knowledge and resources in the financial field to invest in financial assets. On the other hand, executives with financial connections can also obtain more credit funds for enterprises, and a relatively loose capital environment can indirectly increase executives' willingness to invest in financial assets.

\subsection{Intermediary Effect Test of External Profit Pressure}

For the mediating effect of external profit pressure on the relationship between the margin trading system and enterprise financialization, this paper uses three steps to investigate: the first step is consistent with the benchmark model to investigate the impact of the explanatory variable margin trading system PostList on the financial level finance of the explained variable enterprise, which has been concluded above. The second step is to investigate the influence of the explanatory variable PostList on the intermediary variable external profit pressure GAP. The third step is to introduce the explanatory variable PostList and the intermediary variable GAP into the model to investigate its coefficient and significance level. It can be seen from column (2) of Table 5 that the PostList coefficient is 0.171 , which is significant at the significance level of $1 \%$, indicating that the margin trading system has a significant positive impact on the external profit pressure of enterprises. The implementation of the margin trading system will lead to higher external profit pressure. It can be seen from column (3) that, after the margin trading system and external profit pressure are added to the model simultaneously, both coefficients are positive and significant at the significance level of $1 \%$. This indicates that the external profit pressure plays a partial intermediary role in the relationship between implementing the margin trading system and the enterprise's financialization level; implementing the margin trading system will increase the enterprise's external profit pressure. This further leads to the improvement in the enterprise financialization level, and hypothesis $\mathrm{H} 4$ of this paper is supported. Specifically, financing transactions play a leading role in promoting the rise of enterprise stock prices, and analysts are more likely to release optimistic earnings forecasts for enterprises, resulting in increased pressure on enterprise profits. In this regard, enterprise management tends to increase the willingness to invest in financial assets and enhance the trend of financialization to stabilize stock prices, improve short-term performance, and maintain personal compensation.

Table 5. Intermediary effect of external profit pressure of enterprises.

\begin{tabular}{cccc}
\hline & $\mathbf{( 1 )}$ & $\mathbf{( 2 )}$ & $\mathbf{( 3 )}$ \\
\hline & Finance & GAP & Finance \\
\hline List & -0.001 & $-0.061^{* *}$ & 0.000 \\
& $(-0.61)$ & $(-1.99)$ & $(0.17)$ \\
PostList & $0.002^{*}$ & $0.171^{* * *}$ & $0.004^{* * *}$ \\
GAP & $(1.68)$ & $(6.53)$ & $(2.59)$ \\
& & & $0.002^{* * *}$ \\
Size & & $(3.40)$ \\
& $-0.009^{* * *}$ & $0.094^{* * *}$ & $-0.011^{* * *}$ \\
ROA & $(-8.84)$ & $(5.31)$ & $(-8.29)$ \\
& -0.015 & $3.397^{* * *}$ & $-0.056^{* * *}$ \\
Leverage & $(-1.55)$ & $(14.76)$ & $(-4.27)$ \\
& $-0.004^{* * *}$ & $0.059^{* * * *}$ & $-0.002^{* *}$ \\
Top10 & $(-5.89)$ & $(3.90)$ & $(-2.56)$ \\
& $-0.070^{* * *}$ & $-0.759^{* * * *}$ & $-0.058^{* * *}$ \\
Turnover & $(-12.71)$ & $(-6.52)$ & $(-8.71)$ \\
& $-0.023^{* * *}$ & 0.052 & $-0.012^{* * *}$ \\
Inventory & $(-11.60)$ & $(1.20)$ & $(-4.85)$ \\
& $-0.127^{* * *}$ & $0.824^{* * *}$ & $-0.119^{* * *}$ \\
& $(-18.85)$ & $(4.95)$ & $(-12.96)$ \\
\hline
\end{tabular}


Table 5. Cont.

\begin{tabular}{|c|c|c|c|}
\hline & (1) & (2) & (3) \\
\hline & Finance & GAP & Finance \\
\hline TobinQ & $\begin{array}{c}0.004^{* * *} \\
(8.09)\end{array}$ & $\begin{array}{l}0.004 \\
(0.48)\end{array}$ & $\begin{array}{c}0.003^{* * *} \\
(4.40)\end{array}$ \\
\hline $\mathrm{CFO}$ & $\begin{array}{c}-0.027^{* * *} \\
(-3.82)\end{array}$ & $\begin{array}{c}1.447^{* * *} \\
(9.64)\end{array}$ & $\begin{array}{c}-0.017 * * \\
(-1.99)\end{array}$ \\
\hline CAP & $\begin{array}{c}-0.116^{* * *} \\
(-10.32)\end{array}$ & $\begin{array}{c}-2.052 * * * \\
(-9.66)\end{array}$ & $\begin{array}{c}-0.088^{* * *} \\
(-6.99)\end{array}$ \\
\hline Year & Yes & Yes & Yes \\
\hline Individual & Yes & Yes & Yes \\
\hline Constant & $\begin{array}{c}0.267^{* * *} \\
(20.81)\end{array}$ & $\begin{array}{c}-1.822 * * * \\
(-7.16)\end{array}$ & $\begin{array}{c}0.273^{* * *} \\
(16.01)\end{array}$ \\
\hline $\mathrm{N}$ & 23,498 & 14,700 & 14,700 \\
\hline $\mathrm{R}^{2}$ & 0.102 & 0.058 & 0.099 \\
\hline
\end{tabular}

\subsection{Robustness Test}

In order to enhance the robustness of the empirical results, this paper makes the following robustness tests: first, to alleviate the endogenous problem and test the intertemporal dynamic effect, this paper uses the work of Bertrand and Mullainathan [57] and Hoynes et al. [58] as references. It adds three dummy variables, PostList-1, PostList1, and PostList2, to the benchmark model. PostList-1 means that, if a stock is selected as the subject of margin trading, it will be taken as 1 in the previous year; otherwise, take 0 . PostList1 indicates that, if a stock is selected as the subject of margin trading, it will be taken as 1 in the next year; otherwise, it will be taken as 0; PostList2 means that, if a stock is selected as the subject of margin trading, it will be taken as 1 in the next year; otherwise, it will be taken as 0 . It can be seen from column (1) of Table 6 that the coefficients of PostList-1, PostList, and PostList1 are not significant, while the coefficient of PostList2 is significantly positive, indicating that margin trading can promote the level of enterprise financialization, but there is an obvious lag effect.

Second, excluding the IPO companies in the same year, the test results show that the coefficient of PostList is still significantly positive, which is consistent with the main conclusions above. Third, some samples of this paper were transferred out of the subject matter of margin trading during the research period. After removing these samples, this paper reexamines the relationship between margin trading and enterprise financialization. As shown in column (3), the coefficient of PostList is still significantly positive, indicating that the implementation of a margin trading system can promote enterprise financialization. Fourth, this paper adds the following macroeconomic control variables: GDP growth rate (GDPg), broad money M2 growth rate (M2g), and macroeconomic climate index (Pi). The re-test results are shown in column (4), and the regression results are in line with the basic conclusions of this paper. Fifthly, this paper adds the CSI 300 constituent stock HS as the control variable. If the enterprise belongs to the CSI 300 constituent stock, take 1; otherwise, take 0 . The coefficient shown in the results is still significantly positive, indicating that the margin trading and securities lending is positively correlated with the enterprise financialization, which is consistent with the above conclusion. The conclusion of this paper on the relationship between the margin trading system and enterprise financialization is stable. 
Table 6. The robustness tests.

\begin{tabular}{|c|c|c|c|c|c|}
\hline & (1) & (2) & (3) & (4) & (5) \\
\hline & $\begin{array}{c}\text { Intertemporal } \\
\text { Dynamic Effect }\end{array}$ & $\begin{array}{c}\text { Exclude the } \\
\text { Samples of IPO in } \\
\text { the Current Year }\end{array}$ & $\begin{array}{c}\text { Eliminate the Target } \\
\text { Samples } \\
\text { Transferred out in } \\
\text { the Later Stage }\end{array}$ & $\begin{array}{c}\text { Increase } \\
\text { Macroeconomic } \\
\text { Related Control } \\
\text { Variables }\end{array}$ & $\begin{array}{c}\text { Add Stock Index } \\
\text { Futures } \\
\text { Control Variables }\end{array}$ \\
\hline List & $\begin{array}{l}-0.001 \\
(-0.57)\end{array}$ & $\begin{array}{l}-0.001 \\
(-0.44)\end{array}$ & $\begin{array}{l}-0.000 \\
(-0.21)\end{array}$ & $\begin{array}{l}-0.001 \\
(-0.95)\end{array}$ & $\begin{array}{l}-0.001 \\
(-0.62)\end{array}$ \\
\hline PostList -1 & $\begin{array}{l}0.001 \\
(0.77)\end{array}$ & & & & \\
\hline PostList & $\begin{array}{l}-0.000 \\
(-0.22)\end{array}$ & $\begin{array}{l}0.003 * \\
(1.89)\end{array}$ & $\begin{array}{l}0.002 * \\
(1.68)\end{array}$ & $\begin{array}{l}0.004^{* * *} \\
(3.00)\end{array}$ & $\begin{array}{c}0.002 * \\
(1.66)\end{array}$ \\
\hline PostList 1 & $\begin{array}{l}0.002 \\
(0.70)\end{array}$ & & & & \\
\hline PostList 2 & $\begin{array}{c}0.003 * \\
(1.74)\end{array}$ & & & & \\
\hline Size & $\begin{array}{c}-0.010 * * * \\
(-9.16)\end{array}$ & $\begin{array}{c}-0.010 * * * \\
(-9.67)\end{array}$ & $\begin{array}{c}-0.010^{* * *} \\
(-9.14)\end{array}$ & $\begin{array}{c}-0.006^{* * *} \\
(-6.12)\end{array}$ & $\begin{array}{c}-0.010 * * * \\
(-9.10)\end{array}$ \\
\hline $\mathrm{ROA}$ & $\begin{array}{l}-0.017 * \\
(-1.70)\end{array}$ & $\begin{array}{l}-0.008 \\
(-0.80)\end{array}$ & $\begin{array}{l}-0.015 \\
(-1.46)\end{array}$ & $\begin{array}{c}-0.027^{* * *} \\
(-2.66)\end{array}$ & $\begin{array}{l}-0.016 \\
(-1.59)\end{array}$ \\
\hline Leverage & $\begin{array}{c}-0.004^{* * *} \\
(-5.75)\end{array}$ & $\begin{array}{c}-0.004^{* * *} \\
(-5.67)\end{array}$ & $\begin{array}{c}-0.004^{* * *} \\
(-5.80)\end{array}$ & $\begin{array}{c}-0.004^{* * *} \\
(-6.68)\end{array}$ & $\begin{array}{c}-0.004^{* * * *} \\
(-5.66)\end{array}$ \\
\hline Top10 & $\begin{array}{l}-0.069 * * * \\
(-12.51)\end{array}$ & $\begin{array}{l}-0.064^{* * *} \\
(-11.36)\end{array}$ & $\begin{array}{l}-0.069 * * * \\
(-12.21)\end{array}$ & $\begin{array}{l}-0.082 * * * \\
(-14.79)\end{array}$ & $\begin{array}{l}-0.069 * * * \\
(-12.56)\end{array}$ \\
\hline Turnover & $\begin{array}{l}-0.023^{* * *} \\
(-11.60)\end{array}$ & $\begin{array}{l}-0.023 * * * \\
(-11.10)\end{array}$ & $\begin{array}{l}-0.025^{* * *} \\
(-12.07)\end{array}$ & $\begin{array}{l}-0.022 * * * \\
(-10.78)\end{array}$ & $\begin{array}{l}-0.023 * * * \\
(-11.64)\end{array}$ \\
\hline Inventory & $\begin{array}{l}-0.126^{* * *} \\
(-18.83)\end{array}$ & $\begin{array}{c}-0.131^{* * *} \\
(-19.32)\end{array}$ & $\begin{array}{c}-0.120 * * * \\
(-17.45)\end{array}$ & $\begin{array}{c}-0.131^{* * *} \\
(-19.29)\end{array}$ & $\begin{array}{c}-0.126^{* * *} \\
(-18.84)\end{array}$ \\
\hline TobinQ & $\begin{array}{c}0.004^{* * *} \\
(8.01)\end{array}$ & $\begin{array}{c}0.003^{* * *} \\
(6.76)\end{array}$ & $\begin{array}{c}0.004^{* * *} \\
(7.52)\end{array}$ & $\begin{array}{c}0.003^{* * *} \\
(6.19)\end{array}$ & $\begin{array}{c}0.004^{* * *} \\
(7.83)\end{array}$ \\
\hline $\mathrm{CFO}$ & $\begin{array}{c}-0.027^{* * *} \\
(-3.85)\end{array}$ & $\begin{array}{c}-0.031^{* * *} \\
(-4.34)\end{array}$ & $\begin{array}{c}-0.024^{* * *} \\
(-3.35)\end{array}$ & $\begin{array}{c}-0.013 * \\
(-1.82)\end{array}$ & $\begin{array}{c}-0.027^{* * *} \\
(-3.82)\end{array}$ \\
\hline CAP & $\begin{array}{c}-0.116^{* * *} \\
(-10.34)\end{array}$ & $\begin{array}{c}-0.124^{* * *} \\
(-10.77)\end{array}$ & $\begin{array}{c}-0.118^{* * *} \\
(-10.28)\end{array}$ & $\begin{array}{l}-0.121^{* * *} \\
(-10.76)\end{array}$ & $\begin{array}{c}-0.117^{* * *} \\
(-10.41)\end{array}$ \\
\hline Gdpg & & & & $\begin{array}{c}-0.398^{* * *} \\
(-4.88)\end{array}$ & \\
\hline $\mathrm{M} 2 \mathrm{~g}$ & & & & $\begin{array}{c}-0.050 * * \\
(-2.52)\end{array}$ & \\
\hline $\mathrm{Pi}$ & & & & $\begin{array}{c}0.086^{* * *} \\
(4.59)\end{array}$ & \\
\hline HS & & & & & $\begin{array}{c}0.004^{* *} \\
(2.17)\end{array}$ \\
\hline Year & Yes & Yes & Yes & Yes & Yes \\
\hline Individual & Yes & Yes & Yes & Yes & Yes \\
\hline Constant & $\begin{array}{c}0.273 * * * \\
(20.95)\end{array}$ & $\begin{array}{c}0.281 * * * \\
(21.45)\end{array}$ & $\begin{array}{c}0.272 * * * \\
(20.84)\end{array}$ & $\begin{array}{c}0.194^{* * *} \\
(9.63)\end{array}$ & $\begin{array}{c}0.273^{* * *} \\
(20.82)\end{array}$ \\
\hline $\mathrm{N}$ & 23,498 & 23,498 & 23,498 & 23,498 & 23,498 \\
\hline $\mathrm{R}^{2}$ & 0.102 & 0.099 & 0.101 & 0.080 & 0.102 \\
\hline
\end{tabular}

Note: ${ }^{* * *}, * * *$ indicate, respectively, significant at the level of $1 \%, 5 \%$, and $10 \%$. T value is in parentheses.

Since the regulators have certain standards when formulating the margin trading system and selecting the subject matter of margin trading, there is a certain degree of difference between the subject matter of margin trading and other enterprises, which may lead to significant differences in the degree of financialization between the two types of enterprises before the implementation of the margin trading system, which may affect the above double difference (DID) $[59,60]$ and the validity of the model test results. In this regard, this paper uses Zhao et al. [3] for reference, adopts the propensity matching score method (PSM), and selects enterprise-scale (size), enterprise growth (growth), the shareholding proportion of top ten shareholders (Top10), number of shareholders (HOLD), 
the proportion of transaction amount (TRDPERC), and whether two jobs are one (dual) as PSM matching variables to obtain matching samples according to the selection criteria of financing and securities lending targets and enterprise characteristic variables. The specific construction steps are as follows: in the first step, take the margin trading as the explanatory variable (take 1 for the year in which the enterprise is included in the subject matter of margin trading; otherwise, take 0 ); take the above variables as the explanatory variables and conduct logit regression. In the second step, the nearest neighbor matching method was used to match the control group 1:1, and the common support hypothesis test and parallel trend test were carried out. The third step is to obtain the control group samples with the most similar characteristics to the samples and re-perform the double difference test. This paper is based on the nearest neighbor matching method. According to logit regression, the above explanatory variables are significant to margin trading and securities lending. The logit regression results are not listed here because of the limited space of this paper. Figure 1a,b shows, respectively, the nuclear density functions of the margin trading group and the control group before and after matching. Before matching, it is obvious that the nuclear density functions of the two groups are significantly different. After matching, Figure $1 \mathrm{~b}$ shows that the trend of the nuclear density functions of the two groups is close, indicating that the variable characteristics of the margin trading group and the control group are similar after matching, meeting the common support hypothesis. Table 7 shows the parallel trend test. It can be seen from the table that the errors of the matched samples are less than $10 \%$, and the $p$ values in the t-test test results are more significant than $5 \%$, indicating that there is no significant difference between the matched samples and the sample characteristics before the target company enters the list of margin trading, and the PSM matching effect meets the requirements. After obtaining the matched samples, this paper uses the PSM-DID method to re-test the impact of the margin trading system on enterprise financialization. The test results are shown in Table 8.

Table 7. Analysis of parallel trend test.

\begin{tabular}{ccccccccc}
\hline \multirow{2}{*}{ Variable } & $\begin{array}{c}\text { Unmatched } \\
\text { Matched }\end{array}$ & \multicolumn{2}{c}{ Mean } & \multicolumn{2}{c}{$\%$ Reduct } & \multicolumn{2}{c}{$t$-test } & \multicolumn{2}{c}{ V(T)/ } \\
& Treated & Control & \% Bias & $\mid$ bias $\mid$ & $t$ & $p>|t|$ & V(C) \\
\hline Size1 & $\mathrm{U}$ & 14.337 & 12.636 & 131.5 & & 88.21 & 0 & $1.71^{*}$ \\
& $\mathrm{M}$ & 14.337 & 14.36 & -1.8 & 98.6 & -0.82 & 0.411 & $0.911^{*}$ \\
Growth1 & $\mathrm{U}$ & 13.675 & 17.412 & -10.7 & & -6.53 & 0 & $0.67^{*}$ \\
& $\mathrm{M}$ & 13.675 & 14.011 & -1 & 91 & -0.57 & 0.57 & 0.95 \\
Top10 & $\mathrm{U}$ & 57.799 & 58.385 & -3.6 & & -2.32 & 0.021 & $1.17^{*}$ \\
& $\mathrm{M}$ & 57.799 & 57.948 & -0.9 & 74.6 & -0.44 & 0.657 & $0.82^{*}$ \\
HOLD & $\mathrm{U}$ & 0.021 & 0.0485 & -88.3 & & -50.14 & 0 & $0.26^{*}$ \\
& $\mathrm{M}$ & 0.021 & 0.021 & 0.2 & 99.8 & 0.14 & 0.888 & 1.03 \\
TRDPERC & $\mathrm{U}$ & 3.673 & 3.990 & -10.9 & & -6.98 & 0 & $1.16^{*}$ \\
& $\mathrm{M}$ & 3.673 & 3.602 & 2.5 & 77.4 & 1.28 & 0.2 & $1.07^{*}$ \\
Dual & $\mathrm{U}$ & 0.198 & 0.281 & -19.7 & & -12.19 & 0 & 0 \\
& $\mathrm{M}$ & 0.198 & 0.191 & 1.5 & 92.4 & 0.85 & 0.393 & 0 \\
\hline
\end{tabular}

Note: * indicate, respectively, significant at the level of $10 \%$. T value is in parentheses.

It can be seen from Table 8 that the coefficient of PostList is 0.006 , which is significant at the significance level of $1 \%$, indicating that the test results of the PSM-DID method are consistent with the test results of the whole sample and the margin trading system will promote the financialization level of enterprises. The main conclusions of this paper are robust. 


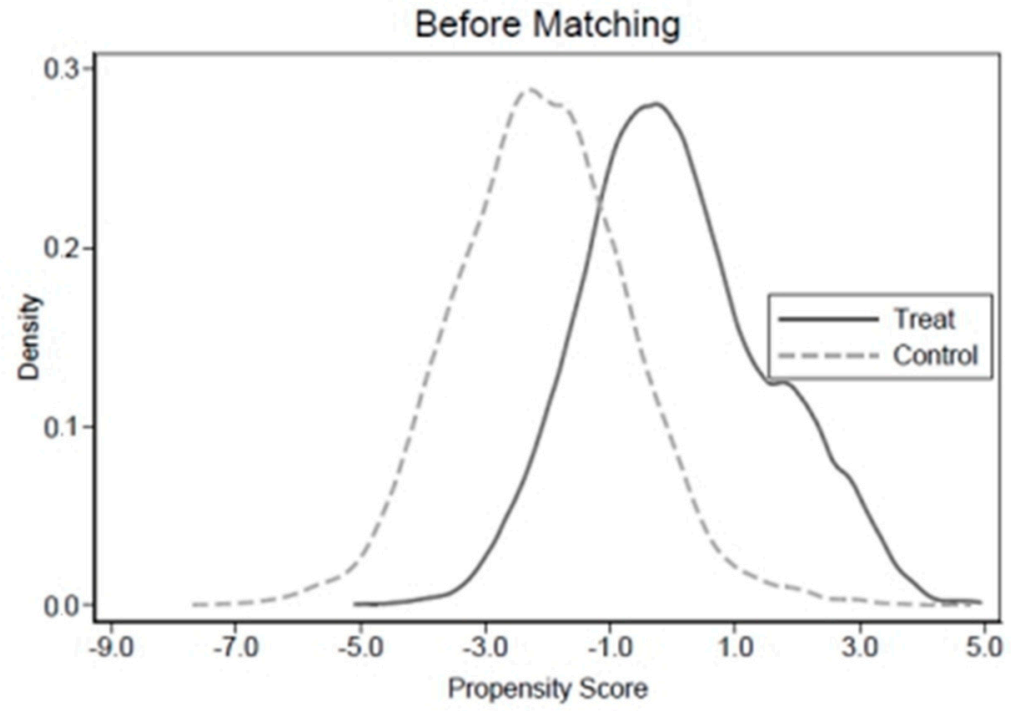

(a)

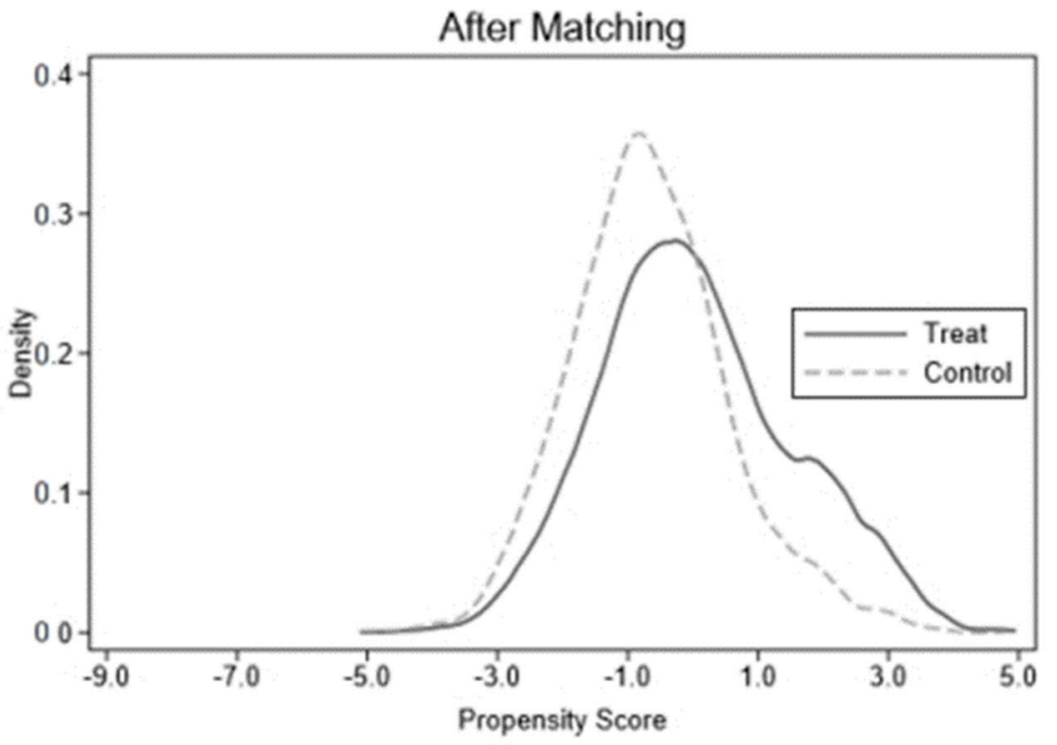

(b)

Figure 1. (a) Kernel density function before matching. (b) Kernel density function after matching.

Table 8. PSM-DID regression result test.

(1)

\begin{tabular}{|c|c|}
\hline & Finance \\
\hline List & $\begin{array}{c}0.003 \text { ** } \\
(2.06)\end{array}$ \\
\hline PostList & $\begin{array}{c}0.006^{* * *} \\
(3.21)\end{array}$ \\
\hline Size & $\begin{array}{c}-0.006^{* * *} \\
(-5.22)\end{array}$ \\
\hline ROA & $\begin{array}{l}-0.000 \\
(-1.11)\end{array}$ \\
\hline Leverage & $\begin{array}{c}-0.003 * * * \\
(-6.23)\end{array}$ \\
\hline
\end{tabular}


Table 8. Cont.

\begin{tabular}{cc}
\hline & $\mathbf{( 1 )}$ \\
\hline Top10 & Finance \\
\hline Turnover & $-0.001^{* * *}$ \\
& $(-13.45)$ \\
Inventory & $-0.015^{* * *}$ \\
& $(-8.99)$ \\
TobinQA & $-0.152^{* * *}$ \\
& $(-19.95)$ \\
CFO & $0.003^{* * *}$ \\
& $(6.09)$ \\
CAP & $-0.033^{* * *}$ \\
& $(-4.16)$ \\
Year & $-0.109^{* * *}$ \\
Individual & $(-7.79)$ \\
Constant & Yes \\
& Yes \\
$\mathrm{N}$ & $0.247^{* * *}$ \\
$\mathrm{R}^{2}$ & $(17.56)$ \\
\hline
\end{tabular}

Note: ${ }^{* * *},{ }^{* *}$ indicate, respectively, significant at the level of $1 \%$ and $5 \%$. T value is in parentheses.

\subsection{Expansion Research: Enterprise Financialization, Margin Trading System, and Enterprise Innovation Level}

According to Wang and Li et al. [41]), there is a substitution relationship between the enterprise financial asset investment and enterprise innovation level. Enterprise financialization will inhibit enterprise innovation levels and "squeeze out" enterprise innovation. The margin trading system is an important measure of China's capital market. Whether the implementation of the system will affect the "crowding out" effect of enterprise financialization on enterprise innovation remains to be verified. This paper makes an empirical test on the above problems by measuring the innovation level of enterprises with $R \& D$ investment. The regression results are shown in Table 9. Column (1) shows that the finance coefficient is significantly negative, indicating that enterprise financialization has an inhibitory effect on the innovation level of enterprises, which is consistent with the conclusions of the existing literature. Column (2), the cross-multiplication term of enterprise financialization finance and PostList of margin trading system, is introduced into the model, and the regression result shows the cross term. The coefficient of Finance $\times$ PostLis is -0.025 , which is significant at the significance level of $1 \%$, indicating that the margin trading system will further aggravate the "crowding out" effect of enterprise financialization on the innovation level. Specifically, on the one hand, the margin trading system will increase the stock price noise through the information mechanism, reduce the degree of information asymmetry, and interfere with the investment decision-making behavior of the management. On the other hand, the margin trading system will affect the salary and reputation of the management through the corporate governance mechanism, bring external pressure to the management, and reduce the high value but slow innovation projects. Therefore, when the financialization of enterprises has a "crowding out effect" on enterprise innovation, enterprises have formed a financialization trend. The margin trading system will increase enterprises' market value and short-term performance, but it will also become a "booster" of enterprise financialization, aggravate the "disenchantment" of entity enterprises, and further reduce the innovation level of enterprises. 
Table 9. The regulatory effect of margin trading on the relationship between enterprise financialization and enterprise innovation.

\begin{tabular}{|c|c|c|}
\hline & (1) & (2) \\
\hline & R\&D & R\&D \\
\hline Finance & $\begin{array}{c}-0.018^{* * *} \\
(-5.09)\end{array}$ & \\
\hline List & & $\begin{array}{c}0.005^{* * *} \\
(7.64)\end{array}$ \\
\hline PostList & & $\begin{array}{c}0.005^{* * *} \\
(5.57)\end{array}$ \\
\hline Finance $\times$ PostList & & $\begin{array}{c}-0.025^{* * *} \\
(-4.74)\end{array}$ \\
\hline Size & $\begin{array}{c}-0.003^{* * *} \\
(-9.38)\end{array}$ & $\begin{array}{c}-0.003^{* * *} \\
(-9.34)\end{array}$ \\
\hline ROA & $\begin{array}{l}-0.003 \\
(-0.47)\end{array}$ & $\begin{array}{l}-0.005 \\
(-0.81)\end{array}$ \\
\hline Leverage & $\begin{array}{c}-0.003 * * * \\
(-9.52)\end{array}$ & $\begin{array}{c}-0.003^{* * *} \\
(-8.75)\end{array}$ \\
\hline Top10 & $\begin{array}{c}-0.004^{* *} \\
(-1.97)\end{array}$ & $\begin{array}{l}-0.003 \\
(-1.52)\end{array}$ \\
\hline Turnover & $\begin{array}{c}-0.024^{* * *} \\
(-30.80)\end{array}$ & $\begin{array}{c}-0.023^{* * *} \\
(-30.36)\end{array}$ \\
\hline Inventory & $\begin{array}{c}-0.037^{* * *} \\
(-11.22)\end{array}$ & $\begin{array}{c}-0.037^{* * * *} \\
(-11.22)\end{array}$ \\
\hline $\mathrm{CFO}$ & $\begin{array}{c}-0.026^{* * *} \\
(-5.13)\end{array}$ & $\begin{array}{c}-0.026^{* * *} \\
(-5.17)\end{array}$ \\
\hline CAP & $\begin{array}{c}0.031^{* * *} \\
(4.50)\end{array}$ & $\begin{array}{c}0.030 * * * \\
(4.38)\end{array}$ \\
\hline TobinQ & $\begin{array}{c}0.005^{* * *} \\
(19.73)\end{array}$ & $\begin{array}{c}0.005^{* * *} \\
(18.36)\end{array}$ \\
\hline Year & Yes & Yes \\
\hline Individual & Yes & Yes \\
\hline Constant & $\begin{array}{c}0.082^{* * *} \\
(12.64)\end{array}$ & $\begin{array}{c}0.085^{* * *} \\
(12.57)\end{array}$ \\
\hline $\mathrm{N}$ & 16,393 & 16,393 \\
\hline $\mathrm{R}^{2}$ & 0.335 & 0.338 \\
\hline
\end{tabular}

Note: ${ }^{* * *},{ }^{* *}$ indicate, respectively, significant at the level of $1 \%$ and $5 \%$. T value is in parentheses.

\section{Conclusions}

\subsection{Summary}

The margin trading system was introduced into China's capital market in 2010. Now, it has experienced nearly 10 years and has been expanded six times. Scholars have always discussed how the margin trading system affects the pricing efficiency of the capital market and the effect of microenterprise governance. This paper constructs a double difference (DID) model to investigate the impact of the margin trading system on the level of enterprise financialization using the micro panel data of Chinese A-share listed companies from 2008 to 2019. The research finds that the margin trading system provides a significant boost to the level of enterprise financialization. As the financing transaction occupies a dominant position in China's capital market, the financing transaction will push up the company's stock price, resulting in the enterprise management being more willing to adopt shortsighted strategies to maintain the stock price and their salary and reputation, prompting the enterprise to adjust the proportion of financial asset allocation. Second, the impact of the margin trading system on the level of enterprise financialization has significant heterogeneity. Compared with non-state-owned enterprises, enterprises with low financing constraints, and enterprises with a high degree of marketization, the boosting effect of the margin trading system on enterprise financialization is more significant in state-owned enterprises, enterprises with high financing constraints, and enterprises with a low degree 
of marketization. Third, the uncertainty of the economic policy has a negative regulatory effect on the relationship between the margin trading system and enterprise financialization. Economic policy uncertainty will aggravate the price fluctuation of financial assets, increase the fluctuation degree of regulatory policies, and increase the financing constraints of enterprises, which will urge the enterprise management to adopt prudent strategies for financial asset investment so that it will weaken the boosting effect of the margin trading system on the level of enterprise financialization. In addition, the executive financial association has a positive regulatory effect on the relationship between the margin trading system and enterprise financialization. Executive financial association means that executives have financial expertise and fund management ability and can use their resources and contacts in the financial field. Therefore, the executive financial association will aggravate the boosting effect of the margin trading system on enterprise financialization. The external profit pressure of enterprises bears part of the intermediary effect in the process that the margin trading system affects the financialization of enterprises. Specifically, the margin trading system will push up the stock price of enterprises. Under the high external profit pressure, enterprises will increase the scale of financial asset allocation to obtain short-term profits to increase the degree of financialization. The intermediary transmission channel of "margin trading system - external profit pressure-enterprise financialization" is effective. Fifth, the expansion research shows that the degree of enterprise financialization will weaken the innovation level of enterprises, and the margin trading system will further aggravate the negative effect of enterprise financialization on the innovation level.

\subsection{Recommendations}

Because of the above conclusions, this paper puts forward the following policy suggestions: first, regulators need to increase the restrictions on the financing scale under the margin trading business to prevent the excessive rise of the share price of listed companies, the excessive easing of financing constraints caused by the high share price of listed companies, the external profit pressure caused by the optimistic deviation of analysts surplus forecast, and the short-sighted behavior of management; this will reduce the trend of enterprise financialization and promote the real economy to "get rid of the virtual to the real". In addition, the extreme imbalance between financing and securities lending transactions in the current margin trading system appropriately reduces the restrictions on short-selling transactions, such as promoting in an orderly manner the expansion process of margin trading and reducing the cost of securities lending. It plays to the governance effect and deterrent effect of the short-selling mechanism, promotes the inclination of enterprise resources to main businesses and innovative projects with long-term value, and ensures a virtuous circle between the capital market and the operation and development of enterprises. Second, it is important to consider that the uncertainty of economic policy has not worsened the current situation of "disenchantment from reality to emptiness" of enterprises but alleviated the role of the margin trading system in promoting the financialization of enterprises. The government needs to establish an economic coordinated regulation and control mechanism based on monetary policy, fiscal policy, and industrial policy and introduce countercyclical regulation ideas to smooth the situation of excessive macroeconomic growth. Therefore, it can improve the expectation of enterprise management for the high rate of return on the investment of financial assets, reduce the short-sighted behavior and financialization tendency of management, and promote China's economy to "get rid of virtual reality". Third, because the financial association of senior executives will aggravate the role of the margin trading system in promoting the financial level of enterprises when selecting senior executives, enterprises should pay attention to the impact of senior executives' background on their decision-making behavior. They should try to diversify senior executives' backgrounds, appropriately reduce the proportion of personnel with the financial association in the senior executives' team, and reduce its "brand" effect. In addition, executives with financial connections should be vigilant when making decisions, take a reasonable view of past financial investment experience and capital operation ability, 
have a clear understanding of the risks faced by enterprises and the applicable degree of financialization, and reduce the negative impact of experience on financial investment decisions. Fourth, since the improvement of the level of financialization will reduce the degree of innovation of enterprises, and the margin trading system will aggravate the decline in the degree of innovation, regulators need to strengthen the supervision of financing transactions and reduce their adverse impact on innovation activities. When expanding the capacity of two financings, they need to pay attention to the degree of enterprise financialization. For enterprises that have formed a trend of financialization, it needs to be carefully included in the two financial targets to prevent the decline in the enterprise innovation level and promote the transformation and upgrading of China's industrial structure.

\subsection{Research limitations}

Fermatean fuzzy sets are commonly used techniques [61,62]; this work can be extended with such aspects in the future. Additionally, this article also has the following shortcomings from the research perspective. The United States introduced the margin trading system in 1934, and institutional investors played a leading role in the capital market. Therefore, American investors are closer to informed traders in the margin trading system. China's margin trading system is still in the early stage of development, and noise investors in the market dominate. Therefore, a unified conclusion regarding whether the margin trading system can play a positive role or not is still unable to be formed. Therefore, China needs to further improve the capital market system and margin trading system to reduce noise investors and give full play to the governance role of the margin trading system.

Author Contributions: Conceptualization, S.G. and H.G.; methodology, S.G.; software, S.G. and H.H.; validation, S.G. and H.G.; formal analysis, S.G. and H.G.; investigation, S.G. and H.G.; resources, S.G.; data curation, S.G.; writing—original draft preparation, S.G.; writing—review and editing, H.H.; visualization, S.G. and H.H.; supervision, H.G.; project administration, H.G.; funding acquisition, H.G. All authors have read and agreed to the published version of the manuscript.

Funding: This research was funded by the Humanities and Social Science Research Program of the Ministry of Education of China under the project, i.e., Mechanism and Policy research on the influence of cross-border capital flow on the credit risk of commercial banks (20YJA790014).

Institutional Review Board Statement: Not applicable.

Informed Consent Statement: Not applicable.

Data Availability Statement: The corresponding author can provide the data on request.

Acknowledgments: The authors would like to extend our sincere thanks to anonymous reviewers for providing helpful comments and suggestions on earlier drafts of the manuscript.

Conflicts of Interest: The authors declare no conflict of interest.

\section{References}

1. Miller, E.M. Risk, uncertainty, and divergence of opinion. J. Financ. 1977, 32, 1151-1168. [CrossRef]

2. Hong, H.; Stein, J.C. Differences of opinion, short-sales constraints, and market crashes. Rev. Financ. Stud. 2003, 16, 487-525. [CrossRef]

3. Zhao, S.M.; Chen, X.Y.; Zhang, J.H. The systemic risk of China's stock market during the crashes in 2008 and 2015. Phys. A Stat. Mech. Appl. 2019, 520, 161-177. [CrossRef]

4. Massa, M.; Qian, W.; Xu, W.; Zhang, H. Competition of the informed: Does the presence of short sellers affect insider selling? J. Financ. Econ. 2015, 118, 268-288. [CrossRef]

5. Li, Y.H.; Zhang, L.D. Short Selling Pressure, Stock Price Behavior, and Management Forecast Precision: Evidence from a Natural Experiment. J. Account. Res. 2015, 53, 79-117. [CrossRef]

6. Grullon, G.; Michenaud, S.; Weston, J.P. The Real Effects of Short-Selling Constraints. Rev. Financ. Stud. 2015, $28,1737-1767$. [CrossRef]

7. Yixin, C.; Junrui, Z.; Fangjun, W. The Effect of Short Selling Mechanism on Listed Firms' Innovation: A Natural Experiment on the Chinese Margin Trading Program. Nankai Bus. Rev. 2018, 21, 62-74.

8. He, J.; Tian, X. Finance and Corporate Innovation: A Survey. Asia-Pac. J. Financ. Stud. 2018, 47, 165-212. [CrossRef] 
9. Wu, D.; Zhu, S.; Memon, A.A.; Memon, H. Financial Attributes, Environmental Performance, and Environmental Disclosure in China. Int. J. Environ. Res. Public Health 2020, 17, 8796. [CrossRef]

10. Chen, L.; Halepoto, H.; Liu, C.; Kumari, N.; Yan, X.; Du, Q.; Memon, H. Relationship Analysis among Apparel Brand Image, Self-Congruity, and Consumers' Purchase Intention. Sustainability 2021, 13, 12770. [CrossRef]

11. Wu, S.; Wu, Y. The Impact of Financialization on Profitability of Real Estate Enterprises. AADN 2020, 476, 58-61. [CrossRef]

12. Orhangazi, O. Financialisation and capital accumulation in the non-financial corporate sector: A theoretical and empirical investigation on the US economy: 1973-2003. Camb. J. Econ. 2008, 32, 863-886. [CrossRef]

13. Shin, H.; Zhao, L.Y. Firms as Surrogate Intermediaries: Evidence from Emerging Economies; Asian Development Bank: Chiyoda, Japan, 2013.

14. Deng, X.-L.; Yan, W.-B. Chinese Style Decentralization, Financialization and Functional Income Distribution: Based on Empirical Tests of the Data from China's Prefecture-Level Cities. Contemp. Financ. Econ. 2019, 9, 48-59. [CrossRef]

15. Maclachlan, F. Repurchase Agreements and the Law: How Legislative Changes Fueled the Housing Bubble. J. Econ. Issues 2014, 48, 515-522. [CrossRef]

16. Allen, F.; Gale, D. Arbitrage, short sales, and financial innovation. Econom. J. Econom. Soc. 1991, 59, 1041-1068. [CrossRef]

17. Goldstein, I.; Guembel, A. Manipulation and the Allocational Role of Prices. Rev. Econ. Stud. 2008, 75, 133-164. [CrossRef]

18. Zhisheng, L.; Chen, C.; Bingxuan, L. Does the short selling mechanism improve the pricing efficiency of China's stock marketevidence based on natural experiments. Econ. Res. 2015, 50, 165-177.

19. Li, K.; Xu, L.; Zhu, W. Short Selling Restriction and Stock Mispricing: Evidence of Margin Trade and Short Selling. Econ. Stud. 2014, 10, 165-178.

20. Huang, H. Margin Trading and Securities Lending, Investor Sentiments and the Volatility of Chinese Securities Market. Am. J. Ind. Bus. Manag. 2019, 9, 536-550. [CrossRef]

21. Sun, C.Y. The Impact of Margin and Short Selling on Stock Pricing Efficiency Based on the Growth Enterprise Market and the Science and Technology Innovation Board. E3S Web Conf. 2021, 292, 1-4. [CrossRef]

22. Karpoff, J.M.; Lou, X. Short Sellers and Financial Misconduct. J. Financ. 2010, 65, 1879-1913. [CrossRef]

23. Sun, H.W.; Yin, S.X. Information leakage in family firms: Evidence from short selling around insider sales. J. Corp. Finance 2017, 47, 72-87. [CrossRef]

24. Wu, G.-Z.; You, D.-M. Margin trading, short selling and corporate green innovation. arXiv 2021, arXiv:2107.11255.

25. Chen, Q.; Goldstein, I.; Jiang, W. Price Informativeness and Investment Sensitivity to Stock Price. Rev. Financ. Stud. 2006, 20, 619-650. [CrossRef]

26. Valaskova, K.; Adamko, P.; Michalikova, K.F.; Macek, J. Quo Vadis, earnings management? Analysis of manipulation determinants in Central European environment. Oeconomia Copernic. 2021, 12, 631-669. [CrossRef]

27. Valáková, K.; Gavurová, B.; Urana, P.; Kováová, M. Alter Ego Only Four Times? The Case Study of Business Profits in the Visegrad Group. Ekon. Manag. 2020, 23, 101-119. [CrossRef]

28. Song, J.; Lu, M. U-shaped relationship between non monetary financial assets and operating returns: Evidence from the financialization of listed non-financial companies in China. Financ. Res. 2015, 6, 111-127.

29. Li, C.; Yao, Q.; Wu, J.; Wang, D. Financialization and risk taking of non-financial corporations empirical evidence from Chinese listed companies. J. Appl. Financ. Bank. 2019, 9, 79-107.

30. He, M. Economic Policy Uncertainty and Enterprise Financialization under the Condition of Informationization. E3S Web Conf. 2021, 251, 01026. [CrossRef]

31. Yuewen, L.; Lu, S. The Overseas Background of Executives and The Financialization of Entity Enterprise study based on STATA. In Proceedings of the 2020 16th Dahe Fortune China Forum and Chinese High-Educational Management Annual Academic Conference (DFHMC), Zhengzhou, China, 4-6 December 2020; pp. 26-29.

32. Bolton, P.; Scheinkman, J.; Xiong, W. Executive Compensation and Short-Termist Behaviour in Speculative Markets. Rev. Econ. Stud. 2006, 73, 577-610. [CrossRef]

33. Wu, S.L.; Zhang, H.J.; Wei, T.Y. Corporate Social Responsibility Disclosure, Media Reports, and Enterprise Innovation: Evidence from Chinese Listed Companies. Sustainability 2021, 13, 8466. [CrossRef]

34. Liu, W.; Cao, Y. Do Institutional Investors Drive Financialization of Real Sectors? China Financ. Econ. Rev. 2019, 8, 25-46.

35. Pownall, G.; Simko, P.J. The Information Intermediary Role of Short Sellers. Account. Rev. 2005, 80, 941-966. [CrossRef]

36. Danielsen, B.R.; Sorescu, S.M. Why Do Option Introductions Depress Stock Prices? A Study of Diminishing Short Sale Constraints. J. Financial Quant. Anal. 2001, 36, 451-484. [CrossRef]

37. Le, Q.V.; Zak, P.J. Political risk and capital flight. J. Int. Money Financ. 2006, 25, 308-329. [CrossRef]

38. Baker, S.R.; Bloom, N.; Davis, S.J. Measuring Economic Policy Uncertainty*. Q. J. Econ. 2016, 131, 1593-1636. [CrossRef]

39. Wang, Y.Z.; Chen, C.R.; Huang, Y.S. Economic policy uncertainty and corporate investment: Evidence from China. Pac. Basin Financ. J. 2014, 26, 227-243. [CrossRef]

40. Opler, T.; Pinkowitz, L.; Stulz, R.; Williamson, R. The Determinants and Implications of Corporate Cash Holdings. J. Financ. Econ. 1997, 52, 3-46. [CrossRef]

41. Wang, H.; Li, Q.; Xin, W. Economic policy uncertainty, cash holdings and market value. J. Financ. Res. 2014, 9, 53-68.

42. Duchin, R.; Gilbert, T.; Harford, J.; Hrdlicka, C. Precautionary Savings with Risky Assets: When Cash Is Not Cash. J. Financ. 2017, 72, 793-852. [CrossRef] 
43. Baum, C.F.; Caglayan, M.; Ozkan, N. The second moments matter: The impact of macroeconomic uncertainty on the allocation of loanable funds. Econ. Lett. 2009, 102, 87-89. [CrossRef]

44. Hambrick, D.C.; Mason, P.A. Upper echelons: The organization as a reflection of its top managers. Acad. Manag. Rev. 1984, 9 , 193-206. [CrossRef]

45. Du, Y.; Xie, J.; Chen, J.-Y. CEO's financial background and the financialization of entity enterprises. China Ind. Econ. 2019, 5, 136-154.

46. Wiersema, M.F.; Zhang, Y. CEO Dismissal: The role of investment analysts. Strat. Manag. J. 2011, 32, 1161-1182. [CrossRef]

47. Zhang, Y.; Gimeno, J. Earnings Pressure and Competitive Behavior: Evidence from the U.S. Electricity Industry. Acad. Manag. J. 2010, 53, 743-768. [CrossRef]

48. Yongming, L.; Yunfeng, L. External Earning Pressure, Diversified Equity Investment and Firm Financialization. J. Financ. Econ. 2019, 45, 73-85. [CrossRef]

49. Kliman, A.; Williams, S.D. Why 'financialisation' hasn't depressed US productive investment. Camb. J. Econ. 2014, 39, 67-92. [CrossRef]

50. Knoerich, J.; Xu, Q. From initiatives to a 'new era'? China's economic policies at the time of the 19th Party Congress. In 19th Party Congress: Start of a New Era; Brown, K., Ed.; World Scientific Publishing Europe: London, UK, 2018; pp. 113-135.

51. Pan, P.; Chao, D.; Yu, Q. Economic Policy Uncertainty, Bank Risk-taking and Firm Investment. J. Financ. Econ. 2020, 46, 67-81. [CrossRef]

52. Wen, Z.; Ye, B. Analysis of mediation effect: Method and model development. Adv. Psychol. Sci 2014, 22, 731-745. [CrossRef]

53. Chai, K.-C.; Yang, Y.; Yeh, C.-P.; Liang, L.-M. External profit pressure and operating efficiency: Evidence from Chinese listed companies. Appl. Econ. 2021, 1-11. [CrossRef]

54. Li, Z.; Wang, Y.; Tan, Y.; Huang, Z. Does Corporate Financialization Affect Corporate Environmental Responsibility? An Empirical Study of China. Sustainability 2020, 12, 3696. [CrossRef]

55. Hadlock, C.J.; Pierce, J.R. New Evidence on Measuring Financial Constraints: Moving Beyond the KZ Index. Rev. Financ. Stud. 2010, 23, 1909-1940. [CrossRef]

56. Wang, X.; Fan, G.; Hu, L. China's Marketization Index Report by Province; Publishing House: Beijing, China, 2016.

57. Bertrand, M.; Mullainathan, S. Enjoying the Quiet Life? Corporate Governance and Managerial Preferences. J. Politi. Econ. 2003, 111, 1043-1075. [CrossRef]

58. Hoynes, H.; Schanzenbach, D.W.; Almond, D. Long-Run Impacts of Childhood Access to the Safety Net. Am. Econ. Rev. 2016, 106, 903-934. [CrossRef]

59. Goodman-Bacon, A. Difference-in-differences with variation in treatment timing. J. Econ. 2021, 225, 254-277. [CrossRef]

60. Callaway, B.; Sant'Anna, P.H.C. Difference-in-Differences with multiple time periods. J. Econ. 2020, 225, 200-230. [CrossRef]

61. Senapati, T.; Yager, R.R. Fermatean fuzzy weighted averaging/geometric operators and its application in multi-criteria decisionmaking methods. Eng. Appl. Artif. Intell. 2019, 85, 112-121. [CrossRef]

62. Sergi, D.; Sari, I.U.; Senapati, T. Extension of capital budgeting techniques using interval-valued Fermatean fuzzy sets. J. Intell. Fuzzy Syst. 2021, 42, 1-12. [CrossRef] 